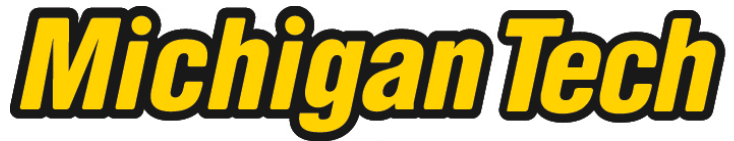 \\ Michigan Technological University Create the Future Digital Commons @ Michigan Tech
}

\section{Will Whole-Tree Harvest of Jack Pine (Pinus banksiana) deplete soil nutrients in low-productivity sand soils?}

Victoria L. Veach

Michigan Technological University

Follow this and additional works at: https://digitalcommons.mtu.edu/etds

Part of the Forest Sciences Commons

Copyright 2011 Victoria L. Veach

\section{Recommended Citation}

Veach, Victoria L., "Will Whole-Tree Harvest of Jack Pine (Pinus banksiana) deplete soil nutrients in lowproductivity sand soils?", Master's report, Michigan Technological University, 2011.

https://doi.org/10.37099/mtu.dc.etds/173

Follow this and additional works at: https://digitalcommons.mtu.edu/etds

8 Part of the Forest Sciences Commons 
Will Whole-Tree Harvest of Jack Pine (Pinus banksiana) Deplete Soil Nutrients in Low-Productivity Sand Soils?

By:

Victoria L. Veach

\begin{abstract}
A REPORT
Submitted in partial fulfillment of the requirements for the degree of MASTER OF SCIENCE IN FOREST ECOLOGY AND MANAGEMENT
\end{abstract}

MICHIGAN TECHNOLOGICAL UNIVERSITY

2011 


\section{Acknowledgements}

I would like to thank my Dr. Martin F. Jurgensen and Jim Gries for their help in development of this project and Prof. Heljä-Sisko Helmisaari for serving as my co-advisor and for her helpful and encouraging comments. I would also like to thank the remaining committee members, Dr. Jim Pickens and Dr. Janice Glime for their support and help on this report. I would like to thank Jim Gries at the Hiawatha National Forest, Dr. Deborah Page-Dumroese at the Rocky Mountain Research Station, and Carolyn Napper at the San Dimas Technology and Development Center for funding this project. I would especially like to thank Dr. Chandrashekhar Joshi for organizing the ATLANTIS program and for giving me the chance to experience life and forestry in Northern Europe. Finally, I would like to thank all my field assistants for their hard work. 


\section{TABLE OF CONTENTS}

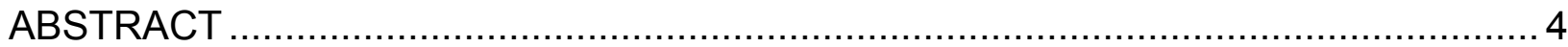

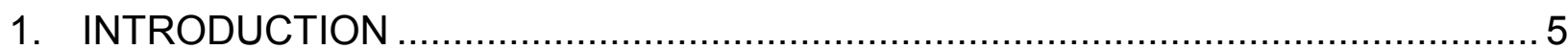

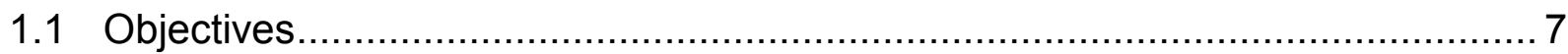

2. METHODS .

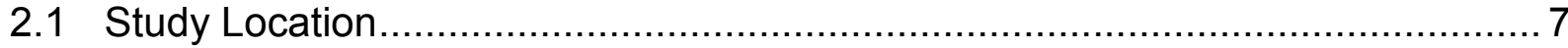

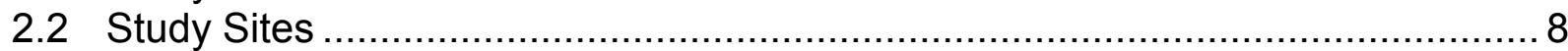

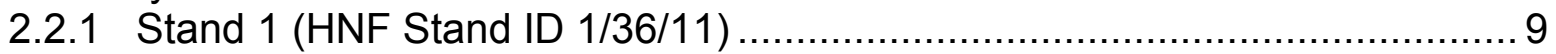

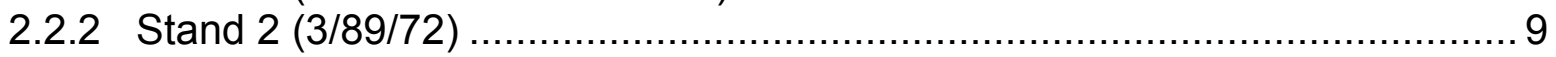

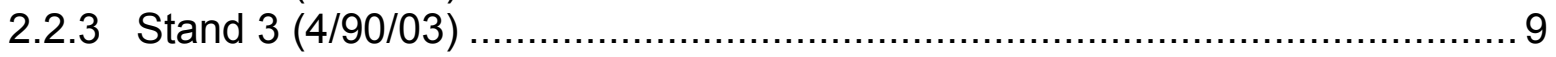

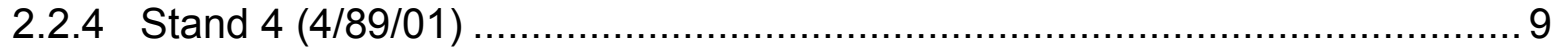

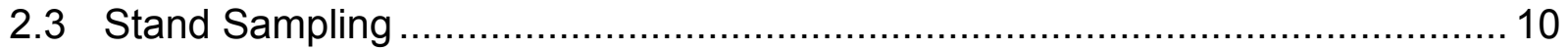

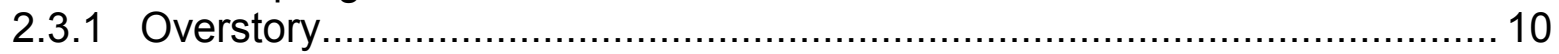

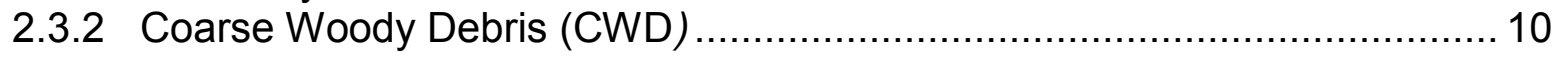

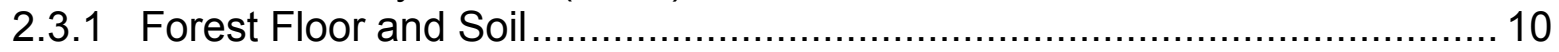

2.4 Sample Preparation and Analysis ............................................................ 11

2.5 Calculation of Biomass and Nutrient Pools.................................................. 12

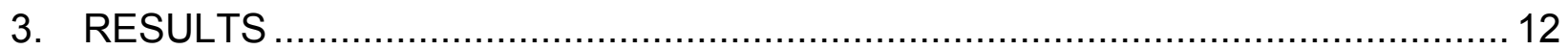

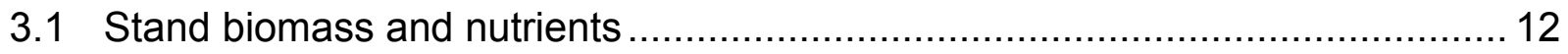

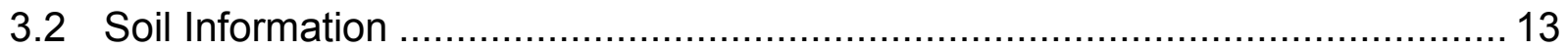

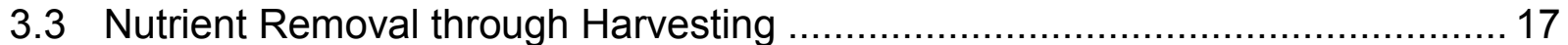

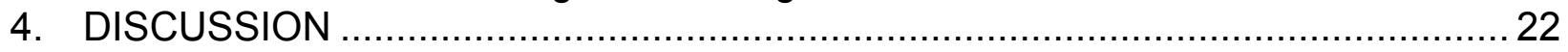

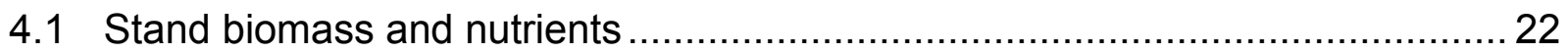

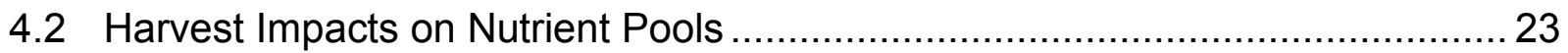

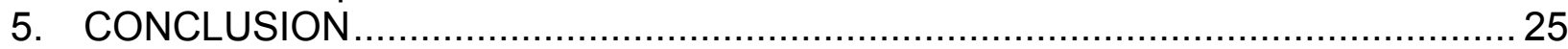

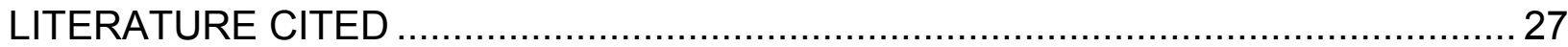

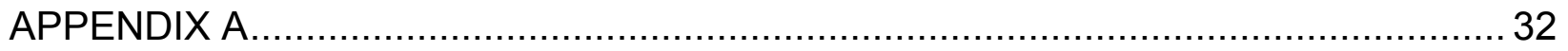

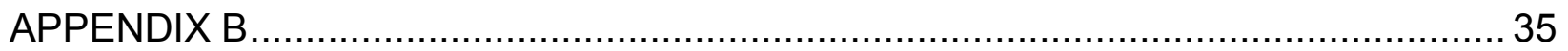




\section{FIGURES}

FIGURE 2.1: LOCATION OF STUDY SITES WITHIN THE HIAWATHA NATIONAL FOREST AND IN MICHIGAN...................... 8

FIGURE 2.2: PLOT DESIGN TO MEASURE CWD BIOMASS IN JACK PINE STANDS ON THE HIAWATHA NATIONAL FOREST (ADAPTED FROM WOODALL AND WILLIAMS 2005) ............................................................................11

FIGURE 3.1: ABOVE-GROUND BIOMASS (TON/HA) OF JACK PINE, RED PINE, AND HARDWOOD SPECIES OF FOUR

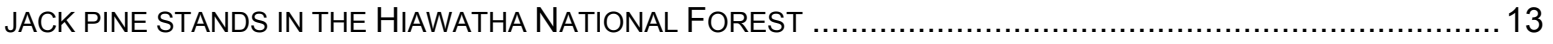

FIGURE 3.2: NUTRIENT CONTENT OF JACK PINE, RED PINE, AND HARDWOOD SPECIES IN FOUR JACK PINE STANDS IN THE HIAWATHA NATIONAL FOREST …………………….........................................................................................14 


\section{TABLES}

TABLE 3.1: MENSURATION DATA AND BIOMASS OF FOUR JACK PINE STANDS IN THE HIAWATHA NATIONAL FOREST

TABLE 3.2: NUTRIENT CONTENT (KG/HA) OF JACK PINE, RED PINE, AND HARDWOODS IN FOUR JACK PINE STANDS IN THE HIAWATHA NATIONAL FOREST …………………………................................................................................

TABLE 3.3: SOIL PHYSICAL PROPERTIES OF FOUR JACK PINE STANDS IN THE HIAWATHA NATIONAL FOREST...........18

TABLE 3.4: CWD AND SOIL NUTRIENT CONTENT IN FOUR JACK PINE STANDS IN THE HIAWATHA NATIONAL FOREST

TABLE 3.5: PERCENT OF NUTRIENTS STORED ABOVE-GROUND (EXCLUDING STUMP) IN FOUR JACK PINE STANDS IN

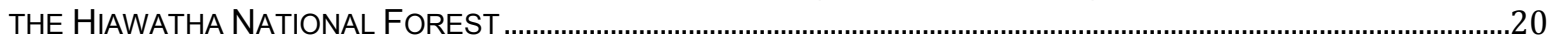

TABLE 3.6: NUtRIENT BUdGET FOR FOUR JACK PINE STANDS IN THE HIAWATHA NATIONAL FOREST..........................21

TABLE A.1: Total ABOVE-GROUND BIOMASS (TON/HA) AND NUTRIENT (KG/HA) ACCUMULATION FOR JACK PINE....32

TABLE A.2: DISTRUBUTION OF BIOMASS (TON/HA) AND NUTRIENTS (KG/HA) IN JACK PINE ...........................................33

TABLE A.3: SoIL NUTRIENT CONTENT UNDER JACK PINE (PERALA AND ALBAN 1982)....................................................34

TAble B.1: Equations used to estimate biomass (From PeRALA AND Alban 1993)............................................35

TABLE B.2: Equations USED to EStimATE CWD WEIGHT AND C (WOOdALL AND WILLIAMS 2005)..........................35

TABLE B.3: NUTRIENT CONCENTRATIONS USED TO ESTIMATED STAND NUTRIENT CONTENT .........................................36 


\begin{abstract}
In 2009 and 2010 a study was conducted on the Hiawatha National Forest (HNF) to determine if whole-tree harvest (WTH) of jack pine would deplete the soil nutrients in the very coarse-textured Rubicon soil. WTH is restricted on Rubicon sand in order to preserve the soil fertility, but the increasing construction of biomass-fueled power plants is expected to increase the demand for forest biomass. The specific objectives of this study were to estimate biomass and nutrient content of above- and below-ground tree components in mature jack pine (Pinus banksiana) stands growing on a coarse-textured, low-productivity soil, determine pools of total C and $\mathrm{N}$ and exchangeable soil cations in Rubicon sand, and to compare the possible impacts of conventional stem-only harvest $(\mathrm{CH})$ and $\mathrm{WTH}$ on soil nutrient pools and the implications for productivity of subsequent rotations. Four even-aged jack pine stands on Rubicon soil were studied. Allometric equations were used to estimate above-ground biomass and nutrients, and soil samples from each stand were taken for physical and chemical analysis. Results indicate that WTH will result in cation deficits in all stands, with exceptionally large Ca deficits occurring in two stands. Where a deficit does not occur, the cation surplus is small and, chemical weathering and atmospheric deposition is not anticipated to replace the removed cations. $\mathrm{CH}$ will result in a surplus of cations, and will likely not result in productivity declines during the first rotation. However even under $\mathrm{CH}$, the surplus is small, and chemical weathering and atmospheric deposition will not supply enough cations for the second rotation.
\end{abstract}




\section{INTRODUCTION}

Biomass utilization has increased in some regions of the world as the push for alternative and renewable energy sources has become stronger (Björheden 2006, Hakkila 2006). Forest residue is one of many types of biomass that can provide a renewable alternative to fossil fuels. Plant litter, however, is one of the most important sources of nutrients returned to the soil as it is an important source of soil organic matter (SOM) and provides much of the annual nutrients required for a forest ecosystem (Waring and Running 2007). SOM also has an important role in long-term site productivity, which can be greatly affected by forest management (Powers 1990, 2004). Intensive silvicultural systems, such as whole-tree harvesting (WTH), that remove fine and non-woody material (branches, foliage, etc.) may have a greater impact on soil productivity than conventional, stem-only, harvest systems $(\mathrm{CH})$ as the concentration of many nutrients is greater in the foliage and branches than in the stem (Farve and Napper 2009). As a result, removing these components would dramatically reduce the amount of potentially mineralizable nutrients returned to the soil as tree litter.

Recent studies suggest that WTH can reduce above-ground productivity (e.g. Stone et al. 1998, Jacobson et al. 2000, Egnell and Valinger 2003, Walmsley et al. 2009, Helmisaari et al. 2011), and that carbon $(C)$ and nitrogen $(N)$ in shallow soil layers, especially the forest floor (FF), are more likely to show a stronger response than deeper soil horizons (e.g. Hendrickson et al. 1989, Olsson et al. 1996, Knoepp and Swank 1997, Nave et al. 2010, Saarsalmi et al. 2010). However, few of these field studies link soil nutrient loss and nutrient removal in harvest to growth reductions.

It is generally thought that WTH will be particularly detrimental to nutrient-poor, low organic matter sandy soils (Lundmark 1983 as seen in Jacobson et al. 1996, Page-Dumroese 2010), as significantly altering the nutrient status of the forest floor (FF) and upper mineral soil horizons could have severe negative implications for future forest and soil productivity. Precautionary biomass harvest guidelines, or best management practices (BMP's), have been developed to address this problem (Minnesota Forest Resource Council 2005, Herrick et al. 2009, MDNR 2010). These BMP's restrict biomass harvesting in certain site types, typically low-productivity sand or shallow soils, to promote long-term site productivity. However, large variation in study design, location, and tree species composition, and a low number of long-term monitoring studies make clear support for this idea relatively limited. For example, Jacobson et al. (2000) found growth reductions of Norway spruce (Picea abies) and Scots pine (Pinus sylvestris) following WTH regardless of climate and soil conditions in Sweden. Stone et al. (1998) found growth reductions of aspen growing on low fertility soil following WTH, but since this study was 
not compared to aspen growing on more productive sites, it is not possible to conclude that productivity losses are worse on low productivity sites.

Determining the long-term impact of WTH is further complicated by the short-term nature of many studies. New long-term studies intended to determine the effects of soil disturbance on soil and forest productivity have been established in North America as part of the Long Term Soil Productivity (LTSP) project, but since the first experiment was established in just 1990 the majority of these studies are still in their infancy (Powers et al. 2005). Even the more established and extensive studies following tree growth from planting are barely 30 years old now, with the most recent reports coming from stands 20 to 24 years old (Egnell and Leijon 1999, Egnell and Valinger 2003, Walmsley et al. 2009).

Jack pine (Pinus banksiana) is an important commercial timber species in Michigan that is often found on coarse-textured low fertility soils, and is typically managed by clear-cut harvesting (Rudolph 1985). Many studies on jack pine have focused on determining the biomass and nutrient content of various tree components, and how nutrients cycle within the ecosystem (e.g. Morrison 1973, Foster and Morrison 1976, Maclean and Wein 1976, Alban et al. 1978, Green and Grigal 1980, Perala and Alban 1982, Alban 1988). Empirical and theoretical WTH studies on jack pine do suggest that this practice will have a negative effect on the soil nutrient status (Weetman and Algar 1983, Thiffault et al. 2006). Weber et al. (1985) concluded that removing the FF in jack pine stands results in reduced basal area and diameter increment. Still, Rothstein and Spalding (2010) conclude that soil and foliar nutrient content in stands treated with WTH will not be statistically different from those regenerating naturally after wildfire.

Currently, WTH of jack pine is widely used on Michigan Department of Natural Resource land at a rate of approximately 3,000 ha/year regardless of site and soil conditions (Mohney 2011, personal communication). In contrast, WTH is not widely used for jack pine management on the Hiawatha National Forest (HNF) in order to prevent declines in soil productivity on very sandy soils (USDA 2006). For example, just two WTH timber sales for jack pine have occurred in recent years (Keach 2011, personal communication).

With increasing construction of biomass-fueled power plants, the demand to maximize forest biomass utilization is expected to increase. Consequently, more information is needed on above- and below-ground nutrient pools in jack pine growing on sandy sites in the HNF, and the possible impact WTH could have on future soil productivity. Furthermore, most studies have determined the nutrient content of stands by chemical analysis of vegetation samples (Weetman and Algar 1983, Helmisaari et al. 2011). But this is cost and time intensive, and methods need 
to be developed in order to quickly and accurately estimate nutrient content of management areas in order to make responsible silvicultural decisions.

\subsection{Objectives}

The objective of this study was to estimate the possible impact of WTH of jack pine on the nutrient status of a low productivity sand soil on the Hiawatha National Forest. Two harvest intensities are considered in this study: Conventional harvest $(\mathrm{CH})$, in which boles to a $10 \mathrm{~cm}$ top are removed, and WTH, in which boles, limbs, and foliage are removed from the site. Due to differences in tree species composition, three further harvest scenarios were considered. The first assumes harvest of only jack pine, the second assumes harvest of jack and red pine, and the third assumes harvest of all merchantable trees (pines and hardwoods). All harvest scenarios assume 100 percent removal efficiency, that is, no residue is lost during transport. All WTH scenarios assume 100 percent removal with no snag or seed tree retention. This entailed:

1) Estimation of the biomass and nutrient content of above- and below-ground tree components in mature jack pine stands growing on a coarse-textured, low-productivity soil.

2) Determination of total soil $\mathrm{C}$ and $\mathrm{N}$ and exchangeable soil cation pools in four representative profiles of this soil.

3) Comparing the possible impacts of $\mathrm{CH}$ and WTH on subsequent soil nutrient pools.

\section{METHODS}

\subsection{Study Location}

This study was conducted in the Hiawatha National Forest (HNF) in Michigan's Upper Peninsula (Figure 2.1). The landforms in the HNF are highly influenced by glacial activity with the last event (the Greatlakean) occurring about 10,000 years ago (Jerome 2006). The growing season in the HNF lasts between 100 and 150 days, with average daily summer and winter temperatures of $17^{\circ}$ and $-7^{\circ} \mathrm{C}$, respectively. The average total annual precipitation is 218 to $645 \mathrm{~cm}$, with most occurring as snow (Jerome 2006). 


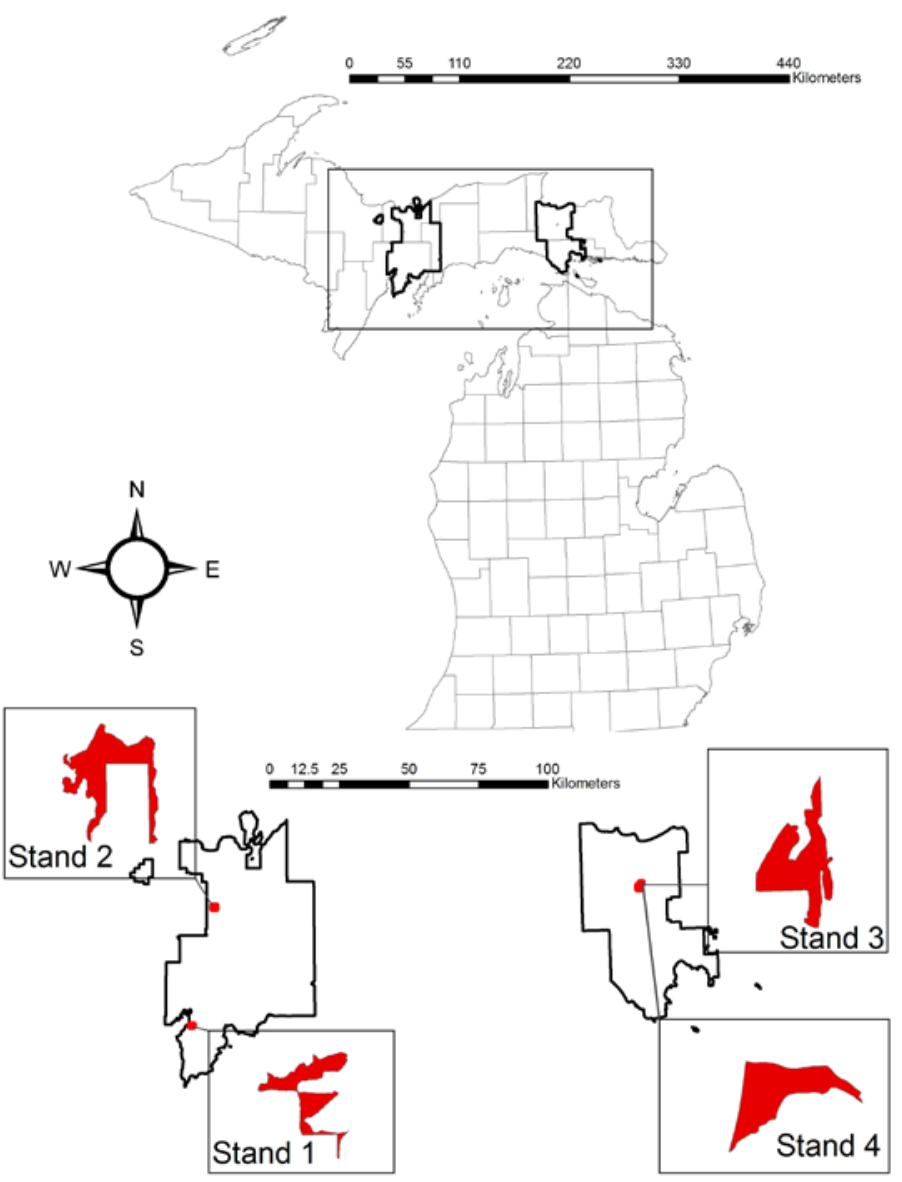

Figure 2.1: Location of study sites within the Hiawatha National Forest and in Michigan

\subsection{Study Sites}

Jack pine was chosen as the focus of this study as it is an important timber species (covering roughly 25,000 ha of the HNF) and is typically found on the low productivity sites where WTH is prohibited on the forest. All jack pine stands used in this study were growing on Rubicon sand, a deep, excessively drained, acid soil, classified as a sandy, mixed, frigid Entic Haplorthod. All stands are classified as Ecological Land Type (ELT) 20, and have a Pinus strobus/Vaccinium angustifolim-Epigaea repens (PVE) site type (Burger \& Kotar 2003). Rubicon sand and ELT 20 are associated with outwash and lake plains, stream terraces, moraines, and beach ridges (USDA 2007, USDA NRCS 2009a), and are major components of the HNF, covering approximately 91,000 ha. 


\subsubsection{Stand 1 (HNF Stand ID 1/36/11)}

Stand $1\left(45^{\circ} 51^{\prime} 54^{\prime \prime} \mathrm{N}, 86^{\circ} 55^{\prime} 57^{\prime \prime} \mathrm{W}\right)$ was established in 1937 and is located on a lake plain in the southern portion of the West Zone of the HNF. Most of this stand is growing on the Grayling soil series, and only the small southern portion on Rubicon soil was sampled. The overstory is dominated by jack pine, and there is a scattered understory of serviceberry (Amelanchier spp.). Common groundflora include low sweet blueberry (Vaccinium angustifolium), bracken fern, bearberry (Arctostaphylos uva-ursi), wintergreen (Gaultheria procumbens), wild lily of the valley (Maianthemum canadense), sedge (Carex spp.), and ground cover mosses.

\subsubsection{Stand $2(3 / 89 / 72)$}

Stand $2\left(46^{\circ} 15^{\prime} 14^{\prime \prime} \mathrm{N}, 89^{\circ} 49^{\prime} 42^{\prime \prime} \mathrm{W}\right)$ was established in 1940 and is located on a pitted outwash plain in the northwestern portion the West Zone of the HNF. The dominant overstory is jack pine with some quaking aspen (Populus tremuloides), pin cherry (Prunus pensylvanica), and red pine (Pinus resinosa) also occurring. The understory consists of scattered red maple (Acer rubrum), white pine (Pinus strobus), balsam fir (Abies balsamea), and serviceberry. Bracken fern is the most abundant groundflora species, but other common groundflora are wintergreen, sedge, low sweet blueberry, trailing arbutus (Epigaea repens), starflower (Trientalis borealis), ground cover mosses, and reindeer lichen (Cladonia spp.).

\subsubsection{Stand $3(4 / 90 / 03)$}

Stand $3\left(46^{\circ} 17^{\prime} 40^{\prime \prime} \mathrm{N}, 84^{\circ} 50^{\prime} 47^{\prime \prime} \mathrm{W}\right)$ was established in 1947 and is located on an outwash plain in the East Zone of the HNF. The dominant overstory is jack pine with scattered red maple and red oak (Quercus rubra) also present. Understory is primarily pin cherry, red oak, and red maple. Common groundflora include bracken fern, low sweet blueberry, trailing arbutus, sedge, reindeer lichen, and ground cover mosses.

\subsubsection{Stand $4(4 / 89 / 01)$}

Stand 4 (46 $\left.{ }^{\circ} 18^{\prime} 36^{\prime \prime} \mathrm{N}, 84^{\circ} 50^{\prime} 10^{\prime \prime} \mathrm{W}\right)$ was established in 1961 and is located on an outwash plain in the East Zone of the HNF. The dominant overstory is jack pine with some red pine also present. Understory consists of scattered red maple. Groundflora is predominantly bracken 
fern, low sweet blueberry, wild lily of the valley, wintergreen, sedge, reindeer lichen, and ground cover mosses.

\subsection{Stand Sampling}

\subsubsection{Overstory}

Above-ground stand data were obtained using a variable radius plot and a basal area factor 10 prism. Since the stands were relatively uniform in age and species, approximately one plot for every four hectares was established. Species, diameter, and status (live/dead) of each tree falling within each plot were recorded. The height of three dominant trees in each plot was also recorded.

\subsubsection{Coarse Woody Debris (CWD)}

Two or three multi-segment coarse woody debris plots were established in each stand, depending on the size of the stand. CWD $(>2.5 \mathrm{~cm})$ was inventoried according to the method utilized in the USFS Forest Inventory Analysis (Figure 2.2), which avoids bias associated with non-random CWD orientation (Woodall and Williams 2005). Mass and C content of CWD were estimated using equations from Woodall and Williams (2005). Nitrogen, Ca, K, and Mg content of CWD were estimated using the weight of the CWD and the stem wood nutrient concentration of jack pine stems (Alban 1988).

\subsubsection{Forest Floor and Soil}

Forest floor (FF) was collected using an $1830 \mathrm{~cm}^{2}$ Daubenmire frame at five random locations in each stand. A $2.5 \mathrm{~cm}$ soil probe was used to collect mineral soil cores to a depth of $30 \mathrm{~cm}$ in each stand, and the horizon thickness in each core was measured. Soil horizons were separated and placed in plastic bags, and both soil and forest floor samples were stored in a cooler at $2^{\circ} \mathrm{C}$ until processing in the laboratory. 

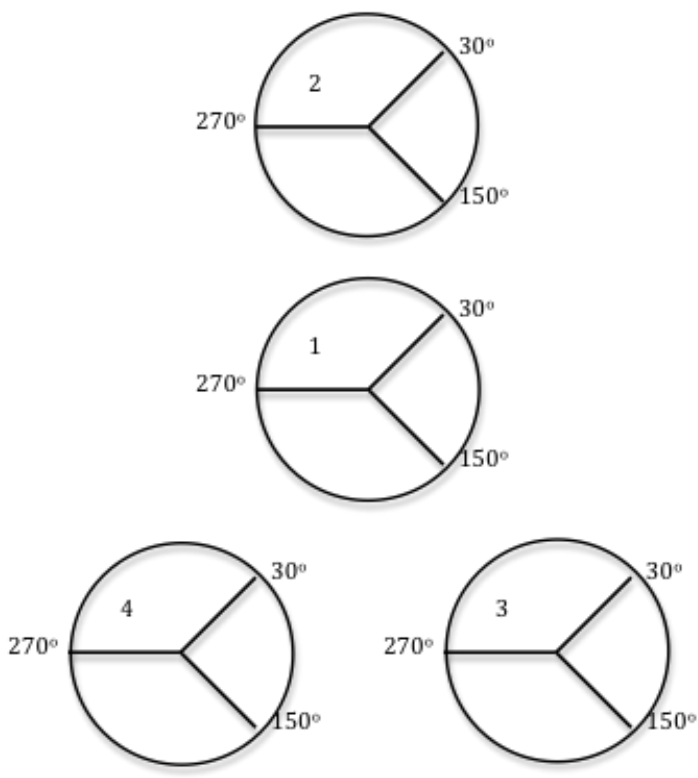

Distance between subplot center 1 and subplot centers 2,3 , and 4 is $36.5 \mathrm{~m}$ at $0^{\circ}$,

$120^{\circ}$, and $240^{\circ}$, respectively. Each transect is $7.3 \mathrm{~m}$.

Figure 2.2: Plot design to measure CWD biomass in jack pine stands on the Hiawatha National Forest (Adapted from Woodall and Williams 2005)

\subsection{Sample Preparation and Analysis}

All soil and forest floor samples were placed in an oven at $105^{\circ} \mathrm{C}$ until dry. Following drying, samples were weighed, and the mineral soil was passed through a $2 \mathrm{~mm}$ sieve. Forest floor samples were ground through a $1 \mathrm{~mm}$ screen. Organic matter was determined by loss-onignition at $400^{\circ} \mathrm{C}$ for 8 hours. Mineral soil texture was determined using the hydrometer method, and the pressure plate method was used to determine available water-holding capacity (AWHC). Nutrient analysis of the FF and mineral soil was conducted at the USDA Forest Service Sciences Laboratory in Moscow, Idaho. Total $\mathrm{C}$ and $\mathrm{N}$ in the FF and mineral soil were determined by dry combustion on a Leco TruSpec CN Analyzer. Mineral soil cations were extracted using pH 7.0 ammonium acetate. Cations in the FF were extracted using $2 \mathrm{~N}$ nitric acid after ashing at $475^{\circ} \mathrm{C}$ for 5 hours. Cations in the FF and mineral soil were analyzed on a PerkinEImer 5100PC Atomic Absorption Spectrometer. 


\subsection{Calculation of Biomass and Nutrient Pools}

Height and above-ground dry weight biomass of foliage ${ }^{1}$, live branches, dead branches, bole bark, bole wood, and stump and coarse root biomass for all tree species were estimated using allometric equations developed by Perala and Alban (1993). Above-ground nutrients for jack pine and red pine were estimated using nutrient concentrations from Alban (1988). Red maple, quaking aspen, red oak, and pin cherry nutrient concentrations were obtained from Rutkowski and Stottlemyer (1993), and Marks (1974). Stem nutrient concentrations were used to estimate root nutrient concentrations of jack pine, red pine, quaking aspen, red oak, and red maple. Nutrient concentration of red maple was estimated using nutrient concentrations for sugar maple (Acer saccharum). Soil bulk density was estimated from percent sand content using equations developed by Broadfoot and Burke (1958).

\section{RESULTS}

\subsection{Stand biomass and nutrients}

The study sites range in age from 49-72 years (Table 3.1). All stands are jack pine dominated, but only stand 1 is pure jack pine. Stand 4 is a mix of jack pine and red pine, while the other two stands have various amounts of hardwoods. The hardwoods contribute little to total stand biomass, but contain an appreciable amount of cations (Tables 3.1 and 3.2, Figures 3.1 and 3.2). This was especially evident for $\mathrm{Ca}$ in the branches and roots of quaking aspen in stand 2, which contained 27 percent of the total above-ground Ca pool. The contribution of dead stems to stand biomass ranged from 2 to 10 percent, while the contribution to total stand nutrients ranged from 1 to 6 percent.

\footnotetext{
${ }^{1}$ Foliage biomass of quaking aspen was estimated using parameters developed for big-tooth aspen (Populus grandidentata) after determining an error existed in the parameters published for quaking aspen.
} 


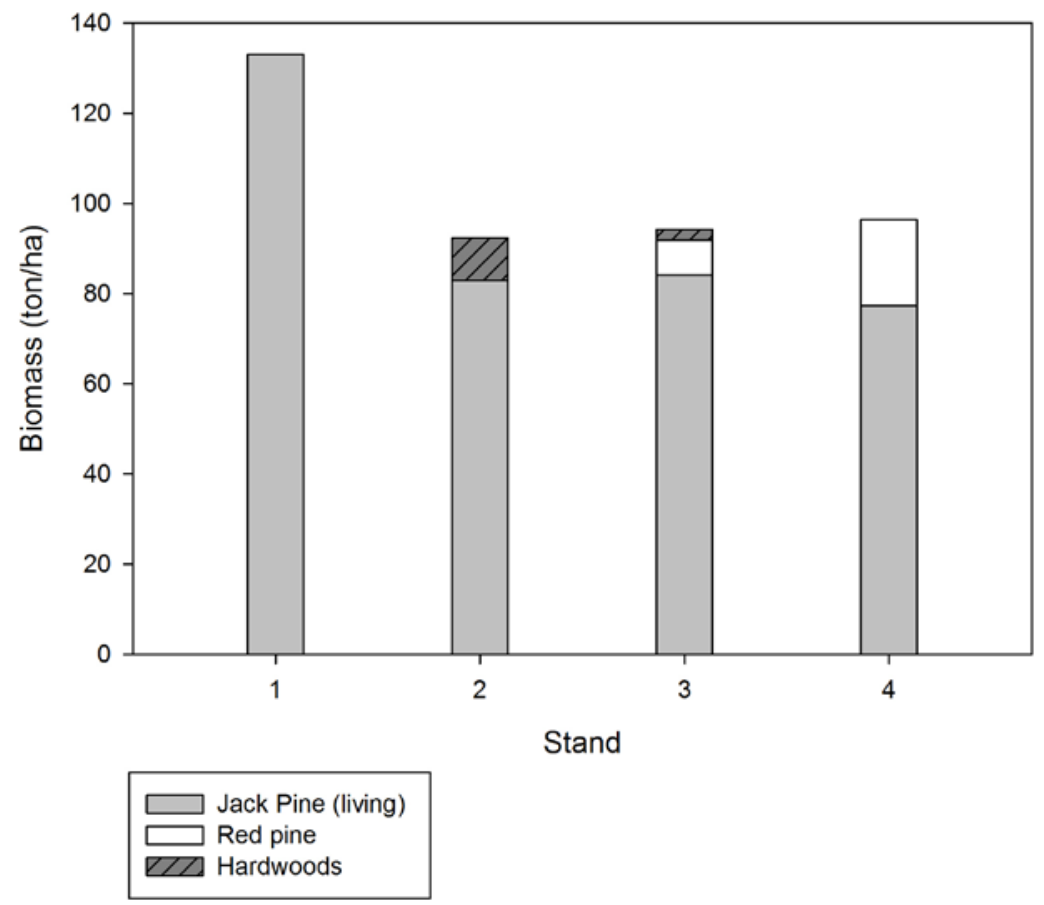

Figure 3.1: Above-ground biomass (ton/ha) of jack pine, red pine, and hardwood species of four jack pine stands in the Hiawatha National Forest

\subsection{Soil Information}

There is little variability in soil $\mathrm{OM}$ content, $\mathrm{AWHC}$, texture, and $\mathrm{pH}$ among the four stands (Table 3.3). The mineral soil in stand 4 has slightly higher fine sand and silt content than the other stands, which is reflected in a slightly higher AWHC. The weight of CWD is highly variable among the sites, which could be related to differences in stand age (Table 3.3).

The amount of total soil C, N, and exchangeable Ca are lowest in stand 3 . Since the concentrations of $\mathrm{C}$ and $\mathrm{N}$ are comparable to that of the other stands, these low values may be due to a thinner $E$ horizon thickness in this stand (Table 3.3). The small $E$ horizon will also contribute to the lower Ca content of this stand, but this can be better explained by the very low Ca concentration in the $\mathrm{Bs}_{1}$ horizon (Table 3.4). In contrast to $\mathrm{Ca}$, the $\mathrm{K}$ content of stand 3 is much higher than that of the others, which can be due to a high $\mathrm{K}$ concentration in the $\mathrm{E}$ horizon (Table 3.4).

The higher soil nutrients in stand 2 could be influenced by the presence of hardwoods, as the $\mathrm{C}$ and $\mathrm{N}$ content and the FF cation concentrations are higher than that of the other stands. The annual shedding of leaves will lead to higher yearly cation inputs to the FF. Shedding of leaves will also positively affect soil N, even though the hardwoods do not contain large amounts of $\mathrm{N}$. 
A. Stand 1

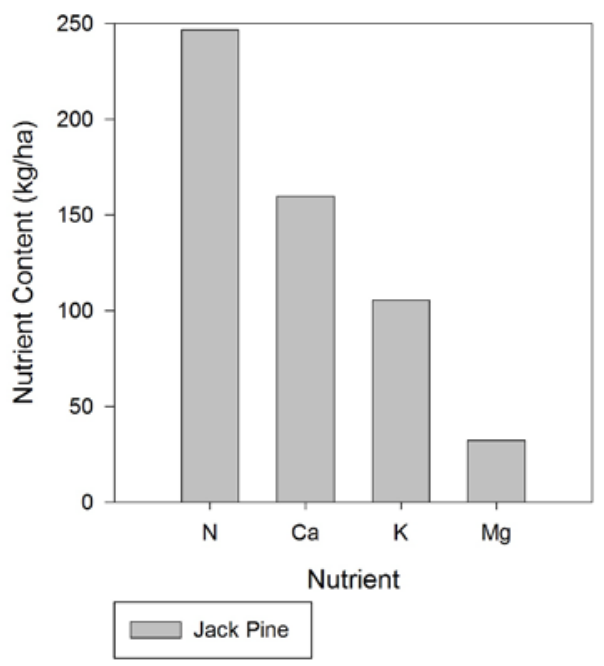

C. Stand 3

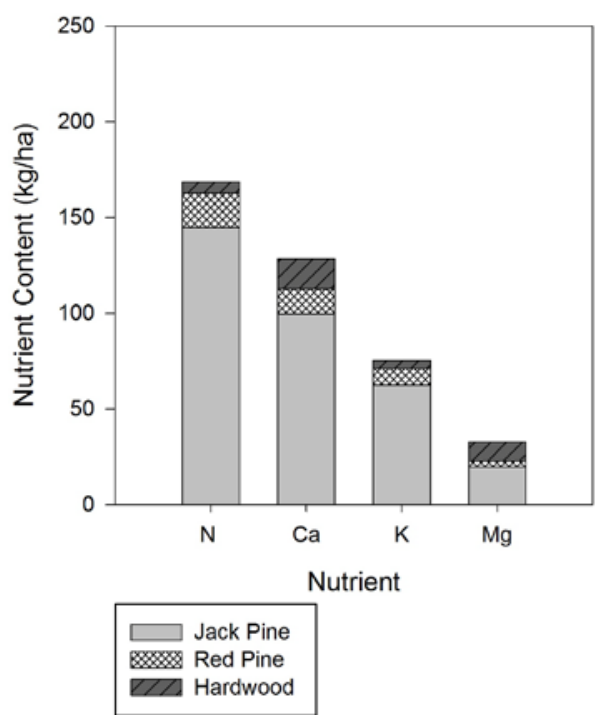

B. Stand 2

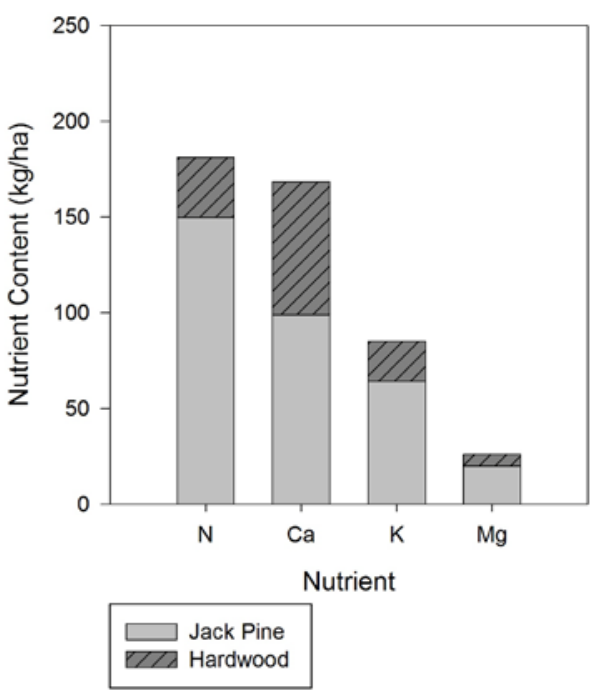

D. Stand 4

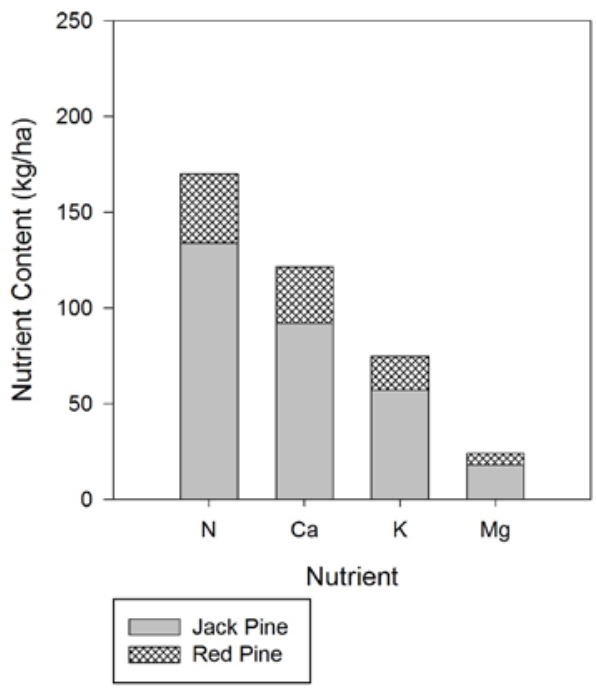

Figure 3.2: Nutrient content of jack pine, red pine, and hardwood species in four jack pine stands in the Hiawatha National Forest 


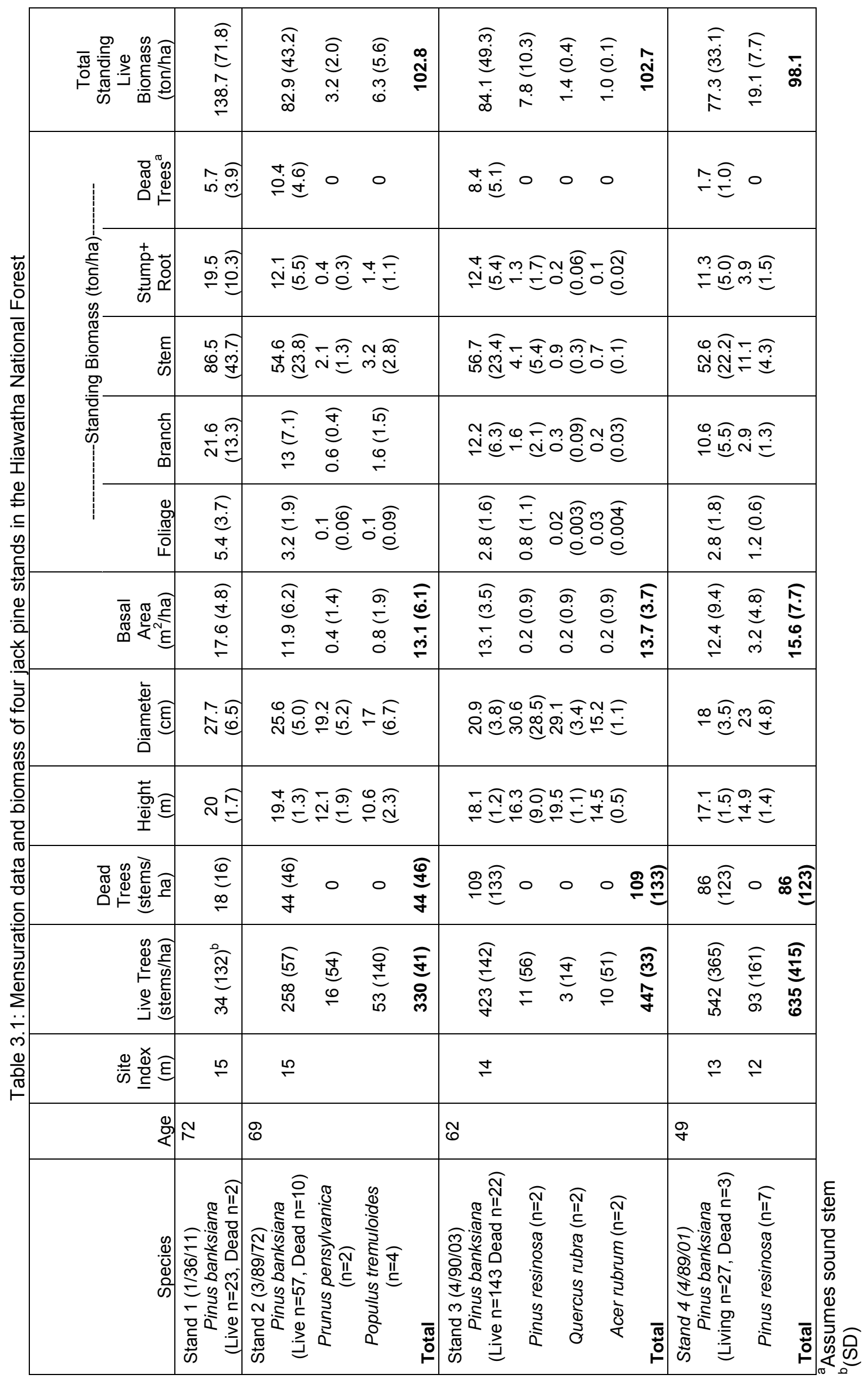


Table 3.2: Nutrient content $(\mathrm{kg} / \mathrm{ha})$ of jack pine, red pine, and hardwoods in four jack pine stands in the Hiawatha National Forest

\begin{tabular}{|c|c|c|c|c|}
\hline & $\begin{array}{c}\text { Nitrogen } \\
(\mathrm{kg} / \mathrm{ha})\end{array}$ & $\begin{array}{c}\text { Calcium } \\
(\mathrm{kg} / \mathrm{ha})\end{array}$ & $\begin{array}{c}\text { Potassium } \\
(\mathrm{kg} / \mathrm{ha})\end{array}$ & $\begin{array}{l}\text { Magnesium } \\
(\mathrm{kg} / \mathrm{ha})\end{array}$ \\
\hline \multirow{2}{*}{\multicolumn{5}{|c|}{$\begin{array}{l}\text { Stand } 1 \\
\text { Live Jack Pine }\end{array}$}} \\
\hline & & & & \\
\hline Foliage & 69.7 & 18.2 & 21.9 & 4.4 \\
\hline Branch & 78.9 & 41.9 & 33.7 & 9.2 \\
\hline Stem & 82.8 & 86.0 & 41.7 & 15.7 \\
\hline Stump+Coarse Root & 15.3 & 13.8 & 8.4 & 3.1 \\
\hline Dead Jack Pine Stem ${ }^{a}$ & 4.5 & 4.1 & 2.5 & 0.9 \\
\hline Total & 251.2 & 164.0 & 108.2 & 33.3 \\
\hline \multicolumn{5}{|l|}{ Stand 2} \\
\hline \multicolumn{5}{|l|}{ Live Jack Pine } \\
\hline Foliage & 40.7 & 10.6 & 12.8 & 2.6 \\
\hline Branch & 47.0 & 25.1 & 19.9 & 5.5 \\
\hline Stem & 52.5 & 54.7 & 26.4 & 10.0 \\
\hline Stump+Coarse Root & 9.6 & 8.6 & 5.2 & 2.0 \\
\hline Dead Jack Pine Stem ${ }^{a}$ & 8.2 & 7.4 & 4.5 & 1.7 \\
\hline Jack Pine Total & 158.0 & 106.4 & 68.8 & 21.8 \\
\hline \multicolumn{5}{|l|}{ Hardwood } \\
\hline Foliage & 5.2 & 2.1 & 2.0 & 0.6 \\
\hline Branch & 12.4 & 32.6 & 7.2 & 2.5 \\
\hline Stem & 7.4 & 16 & 5.2 & 1.4 \\
\hline Stump+Coarse Root & 6.5 & 18.8 & 6.5 & 1.7 \\
\hline Hardwood Total & 31.5 & 69.5 & 20.9 & 6.2 \\
\hline Stand Total & 189.5 & 175.9 & 89.7 & 28.0 \\
\hline \multirow{2}{*}{\multicolumn{5}{|c|}{$\begin{array}{l}\text { Stand } 3 \\
\text { Jack Pine }\end{array}$}} \\
\hline & & & & \\
\hline Foliage & 36.2 & 9.5 & 11.4 & 2.3 \\
\hline Branch & 43.7 & 23.6 & 18.1 & 5.1 \\
\hline Stem & 55.1 & 57.7 & 27.6 & 10.4 \\
\hline Stump+Coarse Root & 9.7 & 8.8 & 5.3 & 2.0 \\
\hline Dead Jack Pine Stem ${ }^{a}$ & 6.6 & 5.9 & 3.6 & 1.3 \\
\hline Jack Pine Total & 151.3 & 105.5 & 66.0 & 21.1 \\
\hline \multicolumn{5}{|l|}{ Red Pine } \\
\hline Foliage & 7.8 & 2.4 & 3.2 & 0.7 \\
\hline Branch & 5.1 & 5.2 & 2.8 & 0.9 \\
\hline Stem & 4.1 & 4.6 & 2.1 & 0.9 \\
\hline Stump+Coarse Root & 1.1 & 1.1 & 0.6 & 0.3 \\
\hline Red Pine Total & 18.1 & 13.3 & 8.7 & 2.8 \\
\hline \multicolumn{5}{|l|}{ Hardwood } \\
\hline Foliage & 1.0 & 0.6 & 0.5 & 0.7 \\
\hline Branch & 2.1 & 5.2 & 1.2 & 0.3 \\
\hline Stem & 2.4 & 9.2 & 2.1 & 0.2 \\
\hline Stump+Coarse Root & 0.4 & 0.4 & 0.5 & 0.04 \\
\hline Hardwood Total & 5.9 & 15.4 & 4.3 & 1.2 \\
\hline Stand Total & 175.3 & 134.2 & 79.0 & 25.1 \\
\hline
\end{tabular}


Table 3.2 (cont.):

\begin{tabular}{|l|c|c|c|c|}
\hline & Nitrogen & Calcium & Potassium & Magnesium \\
\hline Stand 4 & & & & \\
Jack Pine & & & & \\
$\quad$ Foliage & 36.1 & 9.4 & 11.3 & 2.3 \\
$\quad$ Branch & 37.5 & 20.4 & 15.3 & 4.3 \\
$\quad$ Stem & 51.5 & 54.1 & 25.7 & 9.7 \\
Stump+Coarse Root & 8.9 & 8.0 & 4.9 & 1.8 \\
Dead Jack Pine Stem ${ }^{\mathrm{a}}$ & 1.3 & 1.2 & 0.7 & 0.3 \\
Jack Pine Total & $\mathbf{1 3 5 . 3}$ & $\mathbf{9 3 . 1}$ & $\mathbf{5 7 . 9}$ & $\mathbf{1 8 . 4}$ \\
Red Pine & & & & \\
$\quad$ Foliage & 12.0 & 3.8 & 5.0 & 1.1 \\
$\quad$ Branch & 9.2 & 9.5 & 5.1 & 1.7 \\
$\quad$ Stem & 11.5 & 13.0 & 5.8 & 2.5 \\
Stump+Coarse Root & 3.4 & 3.2 & 1.7 & 0.7 \\
Red Pine Total & $\mathbf{3 6 . 1}$ & $\mathbf{2 9 . 5}$ & $\mathbf{1 7 . 6}$ & $\mathbf{6 . 0}$ \\
Stand Total & $\mathbf{1 7 1 . 4}$ & $\mathbf{1 2 2 . 6}$ & $\mathbf{7 5 . 5}$ & $\mathbf{2 4 . 4}$ \\
\hline
\end{tabular}

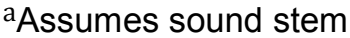

\subsection{Nutrient Removal through Harvesting}

The method used to harvest these low-fertility jack pine stands could have a major impact on soil nutrient pools and future stand growth, as a large portion of the available cation pool (to $30 \mathrm{~cm}$ mineral soil) is stored above-ground (Table 3.5). Harvest intensity will likely have a lesser impact on total soil $\mathrm{N}$ content. When all four stands are considered together, WTH of just jack pine will remove an average of $22 \%$ more biomass, $62 \%$ more $\mathrm{N}, 39 \%$ more $\mathrm{Ca}, 54 \%$ more $\mathrm{K}$, and $44 \%$ more $\mathrm{Mg}$ than $\mathrm{CH}$ of jack pine only. Removing hardwoods during WTH of stands 2 and 3 will remove $17 \%$ more N, 27-56\% more Ca, 20-24\% more K, and 20-25\% more Mg compared to WTH of just jack pine. The high Ca content of hardwood branches in stand 2 considerably increases the amount of Ca removed during total stand WTH. With the exception of Ca, leaving hardwoods but removing conifers during WTH of stand 3 will only slightly decrease nutrient removal. In stand 4, however, red pine has larger contributions to the aboveground nutrient pools, and removing red pine during WTH will remove $26 \%$ more N, $31 \%$ more $\mathrm{Ca}, 30 \%$ more $\mathrm{K}$, and $33 \%$ more $\mathrm{Mg}$ as compared to WTH of jack pine only. 


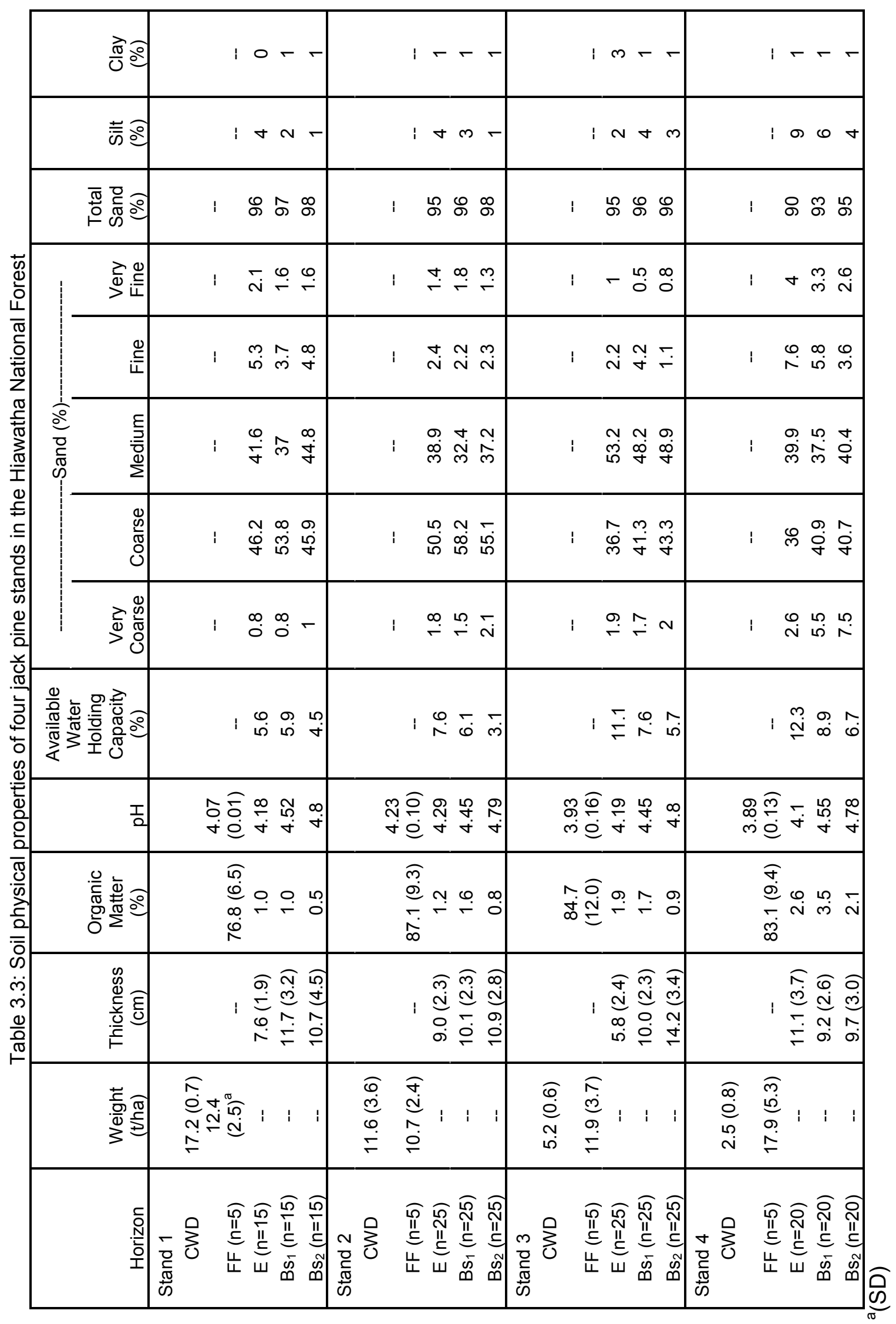




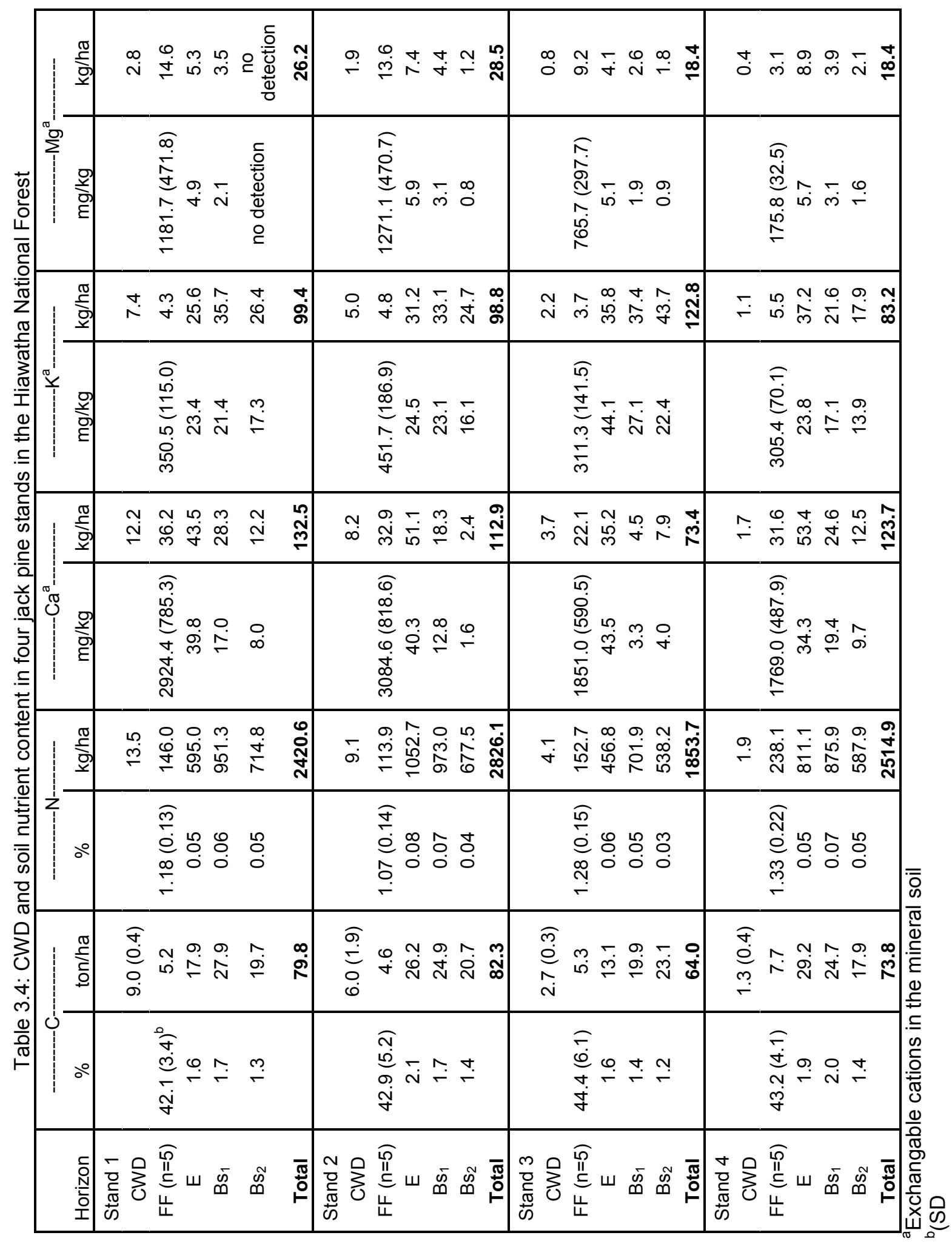


Table 3.5: Percent of nutrients stored above-ground (excluding stump) in four jack pine stands in the Hiawatha National Forest

\begin{tabular}{|c|c|c|c|c|c|c|c|c|}
\hline \multirow{2}{*}{ Stand } & \multicolumn{2}{|c|}{$\mathrm{N}^{\mathrm{a}}$} & \multicolumn{2}{|c|}{$\mathrm{Ca}^{\mathrm{b}}$} & \multicolumn{2}{|c|}{$\mathrm{K}^{\mathrm{b}}$} & \multicolumn{2}{|c|}{$\mathrm{Mg}^{\mathrm{b}}$} \\
\hline & $\mathrm{kg} / \mathrm{ha}$ & $\%$ & $\mathrm{~kg} / \mathrm{ha}$ & $\%$ & $\mathrm{~kg} / \mathrm{ha}$ & $\%$ & $\mathrm{~kg} / \mathrm{ha}$ & $\%$ \\
\hline \multicolumn{9}{|l|}{ Stand 1} \\
\hline Above-ground ${ }^{c}$ & 231.2 & 8.7 & 146.1 & 50.0 & 97.3 & 47.4 & 29.3 & 50.0 \\
\hline Below-ground $^{d}$ & 2435.9 & 91.3 & 146.3 & 50.0 & 107.8 & 52.5 & 29.3 & 50.0 \\
\hline Total & 2667.1 & & 292.4 & & 205.1 & & 58.6 & \\
\hline \multicolumn{9}{|l|}{ Stand 2} \\
\hline Above-ground & 164.7 & 5.5 & 141.1 & 50.1 & 73.5 & 39.9 & 22.6 & 41.2 \\
\hline Below-ground & 2842.2 & 94.5 & 140.3 & 49.9 & 110.5 & 60.1 & 32.2 & 58.7 \\
\hline Total & 3006.9 & & 281.4 & & 184.0 & & 54.8 & \\
\hline \multicolumn{9}{|l|}{ Stand 3} \\
\hline Above-ground & 157.5 & 7.8 & 118.0 & 58.5 & 69.0 & 34.8 & 21.5 & 51.8 \\
\hline Below-ground & 1864.9 & 92.2 & 83.7 & 41.5 & 129.2 & 65.2 & 20.0 & 48.2 \\
\hline Total & 2022.4 & & 201.7 & & 198.2 & & 41.5 & \\
\hline \multicolumn{9}{|l|}{ Stand 4} \\
\hline Above-ground & 157.8 & 5.9 & 110.2 & 45.0 & 68.2 & 43.2 & 21.6 & 50.8 \\
\hline Below-ground & 2527.2 & 94.1 & 134.9 & 55.0 & 89.8 & 56.8 & 20.9 & 49.2 \\
\hline Total & 2685.0 & & 245.1 & & 158.0 & & 42.5 & \\
\hline
\end{tabular}

${ }^{\mathrm{a}}$ Total $\mathrm{N}$

${ }^{\mathrm{b}}$ Exchangeable cations in the mineral soil

Includes bole, limbs, and foliage

${ }^{\mathrm{d}}$ Includes, stump, coarse roots, total $\mathrm{N}$ and cations in FF, total $\mathrm{N}$ and exchangeable cations in top $30 \mathrm{~cm}$ of mineral soil

A nutrient budget for a 65-year-old jack pine stand regenerating after various degrees of harvest intensity was constructed using values of mean annual accumulation over the period 020 years, 20-30 years, and 30-65 years estimated by Foster and Morrison (1976). Available N was estimated as a percentage of total $\mathrm{N}$ based on values of total and available $\mathrm{N}$ determined by Foster and Morrison (1976). In all harvest scenarios, the amount of total $\mathrm{N}$ left on site is more than what would be needed during the first 65 years of stand growth, but very large deficits occur when available $\mathrm{N}$ is considered (Table 3.6). $\mathrm{CH}$ of stands 1,2 , and 4 will leave enough cations on site for the regenerating stand while all $\mathrm{CH}$ scenarios in stand 3 will result in Ca deficits. Ca deficits will also occur following total stand WTH of all stands, with especially large $\mathrm{Ca}$ deficits occurring following all WTH scenarios in stand 3. Leaving hardwood species as retention during harvest has a large influence in the amount of nutrients left on-site in stand 2 due to the high amount of $\mathrm{Ca}$ found in the branches and roots of quaking aspen. 
Table 3.6: Nutrient budget for four jack pine stands in the Hiawatha National Forest

\begin{tabular}{|c|c|c|c|c|c|c|c|c|c|c|c|c|c|c|}
\hline \multirow[b]{3}{*}{ Stand 1} & \multicolumn{5}{|c|}{$\begin{array}{l}\text { Sum Left On Site After Harvest } \\
\qquad(\mathrm{kg} / \mathrm{ha})\end{array}$} & \multicolumn{4}{|c|}{$\begin{array}{l}\text { Amount needed for jack pine } \\
(\text { ages } 1-65)^{\mathrm{a}}(\mathrm{kg} / \mathrm{ha})\end{array}$} & \multicolumn{5}{|c|}{ Difference $(\mathrm{kg} / \mathrm{ha})$} \\
\hline & $\begin{array}{l}\text { Total } \\
\mathrm{N}\end{array}$ & $\begin{array}{c}\text { Avail. } \\
\mathrm{N}^{\mathrm{b}}\end{array}$ & $\mathrm{Ca}^{f}$ & $K^{f}$ & $\mathrm{Mg}^{\mathrm{f}}$ & $\mathrm{N}$ & $\mathrm{Ca}$ & $\mathrm{K}$ & $\mathrm{Mg}$ & $\begin{array}{c}\text { Total } \\
\mathrm{N}\end{array}$ & $\begin{array}{l}\text { Avail. } \\
\mathrm{N}\end{array}$ & $\mathrm{Ca}$ & $\mathrm{K}$ & $\mathrm{Mg}$ \\
\hline & & & & & & & & & & & & & & \\
\hline $\mathrm{CH}$ & 2589 & 19 & 211 & 166 & 44 & 207 & 155 & 106 & 27 & 2382 & -188 & 56 & 60 & 17 \\
\hline WTH & 2440 & 17 & 150 & 110 & 30 & 207 & 155 & 106 & 27 & 2233 & -190 & -5 & 4 & 3 \\
\hline $\begin{array}{l}\text { Stand } 2 \\
\text { Jack pine }^{\mathrm{c}}\end{array}$ & & & & & & & & & & & & & & \\
\hline $\mathrm{CH}$ & 2963 & 21 & 234 & 162 & 47 & 207 & 155 & 106 & 27 & 2756 & -186 & 79 & 56 & 20 \\
\hline WTH & 2875 & 21 & 198 & 129 & 38 & 207 & 155 & 106 & 27 & 2668 & -186 & 43 & 23 & 11 \\
\hline Total Stand ${ }^{e}$ & & & & & & & & & & & & & & \\
\hline $\mathrm{CH}$ & 2956 & 21 & 218 & 157 & 45 & 207 & 155 & 106 & 27 & 2749 & -186 & 63 & 51 & 18 \\
\hline WTH & 2850 & 20 & 148 & 115 & 34 & 207 & 155 & 106 & 27 & 2643 & -187 & -7 & 9 & 7 \\
\hline $\begin{array}{l}\text { Stand } 3 \\
\text { Jack pine }^{\mathrm{c}}\end{array}$ & & & & & & & & & & & & & & \\
\hline $\mathrm{CH}$ & 1974 & 14 & 150 & 174 & 33 & 207 & 155 & 106 & 27 & 1767 & -193 & -5 & 68 & 6 \\
\hline $\begin{array}{l}\text { WTH } \\
\text { Jack pine/Red } \\
\text { pine }^{d}\end{array}$ & 1894 & 14 & 117 & 145 & 26 & 207 & 155 & 106 & 27 & 1687 & -193 & -38 & 39 & -1 \\
\hline $\mathrm{CH}$ & 1970 & 14 & 145 & 172 & 32 & 207 & 155 & 106 & 27 & 1763 & -193 & -10 & 66 & 5 \\
\hline WTH & 1877 & 13 & 105 & 137 & 23 & 207 & 155 & 106 & 27 & 1670 & -194 & -50 & 31 & -4 \\
\hline Total Stand ${ }^{e}$ & & & & & & & & & & & & & & \\
\hline $\mathrm{CH}$ & 1967 & 14 & 136 & 170 & 32 & 207 & 155 & 106 & 27 & 1760 & -193 & -19 & 64 & 5 \\
\hline WTH & 1871 & 13 & 90 & 133 & 22 & 207 & 155 & 106 & 27 & 1664 & -194 & -65 & 27 & -5 \\
\hline $\begin{array}{l}\text { Stand } 4 \\
\text { Jack pine }\end{array}$ & & & & & & & & & & & & & & \\
\hline $\mathrm{CH}$ & 2635 & 19 & 192 & 133 & 33 & 207 & 155 & 106 & 27 & 2428 & -188 & 37 & 27 & 6 \\
\hline $\begin{array}{l}\text { WTH } \\
\text { Jack pine/Red } \\
\text { pine }^{d}\end{array}$ & 2561 & 18 & 162 & 106 & 26 & 207 & 155 & 106 & 27 & 2354 & -189 & 7 & 0.4 & -1 \\
\hline $\mathrm{CH}$ & 2623 & 19 & 179 & 127 & 31 & 207 & 155 & 106 & 27 & 2416 & -188 & 24 & 21 & 4 \\
\hline WTH & 2529 & 18 & 136 & 91 & 21 & 207 & 155 & 106 & 27 & 2322 & -189 & -19 & -15 & -6 \\
\hline
\end{tabular}

${ }^{a}$ Adapted from Foster and Morrison (1976)

${ }^{b}$ Estimated as percentage of total $\mathrm{N}$ based on total and available $\mathrm{N}$ values from Foster and Morrison (1976)

${ }^{\mathrm{c} A s s u m e s ~ j a c k}$ pine harvest only; all other species left as retention trees

${ }^{d}$ Assumes jack pine and red pine harvest; hardwoods left as retention trees

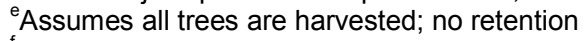

${ }^{\mathrm{f}}$ Total in FF, exchangeable in mineral soil 


\section{DISCUSSION}

\subsection{Stand biomass and nutrients}

Estimated total aboveground biomass and nutrients in these four jack pine sites are comparable to published values for jack pine stands of similar age (Table A.1). The measured height of dominant trees in each plot was compared to the estimated height of those same trees in order to determine the reliability of the allometric height estimators. This showed that allometric estimators tended to overestimate height. Care was taken to locate allometric estimators developed in similar site and soil conditions as the study sites. However, Perala and Alban (1993) biomass equations were developed from stands growing on Grafton sand (Coarse-loamy, mixed, mesic Entic Haplorthod), Redby loamy fine sand (Mixed, frigid Aquic Udipsamment), and Kalkaska sand (Sandy, isotic, frigid Typic Haplorthod), all of which exhibit properties of sites more productive than Rubicon soil. Grafton and Redby sands are characterized by finer, loamy texture while Kalkaska sand is associated with organic matter accumulation in a Bhs horizon and ortstein columns (USDA NRCS 2006a, 2006b, 2010). The slightly finer texture of Grafton and Redby sands will likely retain more organic matter and water than the very coarse textured Rubicon (Bot and Benites 2005). Deeper organic matter accumulation in Kalkaska sand will serve as a source of nutrients as well as aiding in preventing nutrient loss by increasing cation exchange capacity (Bot and Benites 2005). Differences in productivity can also be seen in differences in cation exchange capacity (CEC) among the soil. Rubicon sand has a CEC of just $2.6 \mathrm{cmol} / \mathrm{kg}$ (USDA NRCS 2009b), while Redby and Kalkaska sands have CECs of 3.8 and $160 \mathrm{cmol} / \mathrm{kg}$, respectively (USDA NRCS 2009b). The higher CEC of these soils will help the soil retain cations necessary for plant growth. Differences in soil properties among the study sites and those where biomass estimators were developed, as well as the overestimated height, may lead to inaccurate estimations. However, considering that the total biomass of these stands is comparable to the literature, I feel that the biomass estimation is still within a reasonable source of error.

The method used to estimate CWD nutrient content could also result in an overestimation as nutrient concentration will change as the wood decomposes. However, the wood volume and decay class will be reflected in the nutrient estimation as these factors were used to determine CWD weight. Furthermore, I feel that this method reduces uncertainty associated with using published values as differences with age and amount of CWD have been eliminated. 
Soil $\mathrm{C}$ and $\mathrm{N}$ values in the study sites are comparable with values found by Perala and Alban (1982), while exchangeable Ca, K, and Mg in the study sites are lower (Table A.3). Lower exchangeable cations in the study sites may be due to differences in productivity and soil texture in the study sites and that of published literature.

\subsection{Harvest Impacts on Nutrient Pools}

WTH of these jack pine stands will leave much more total $\mathrm{N}$ than what is needed by the next rotation. However, only a small portion of the total soil $\mathrm{N}$ in jack pine stands is available for tree uptake as Foster and Morrison (1976) found just $29 \mathrm{~kg} / \mathrm{ha}$ available $\mathrm{N}$ in a total $\mathrm{N}$ pool of 4,057 $\mathrm{kg} / \mathrm{ha}$ in the organic and mineral soil under a 30-year-old jack pine stand in Ontario. All harvest scenarios will create very large deficits of available $\mathrm{N}$.

WTH will result in large $\mathrm{Ca}$ deficits and smaller $\mathrm{K}$ and $\mathrm{Mg}$ deficits. Ca deficits are especially large in stand 3 and following total stand harvest of stand 4 . Total stand WTH of stand 4 will also result in large $\mathrm{K}$ deficits. However, retaining red pine during WTH of stand 4 does not increase the nutrient retention so much that a nutrient deficiency would not be of serious concern. Leaving hardwoods as retention during WTH of stand 2 does considerably increase the nutrient pool left on-site following WTH, but since many of these nutrients would be sequestered in the living tissues of the hardwood trees, nutrient availability for the subsequent rotation may still be a concern.

Soil nutrients are most likely to show the sharpest change during the first years following harvest (Knoepp and Swank 1997). Ground vegetation can play a large role in nutrient retention (Crow et al. 1991), but since forest harvest results in large-scale disturbance (Grigal 2000), re-vegetation may not occur right away. This could be especially detrimental to these sites as coarse-texture and low mineral soil OM may make them more susceptible to leaching loss. Furthermore, removing slash during WTH can increase the temperature and moisture of the soil by increased energy absorption (Hornbeck 1970, Kubin and Kemppainen 1991, Keenan and Kimmins 1993) and decreased transpiration (Keenan and Kimmins 1993). Soil temperature and moisture are two main factors controlling decomposition rates (Berg and McClaugherty 2003), and increasing these variables has been shown to increase soil microbe activity (Swift et al. 1979, Jurgensen et al. 1997) and subsequent decomposition rates. Evidence suggests that leaching losses of nutrients increases immediately after harvest, regardless of intensity (Mann et al. 1988), and greater decomposition and decreased vegetation to uptake newly available nutrients immediately following WTH could potentially increase leaching losses. 
Leaching loss of soil nutrients following timber harvest is likely on these coarse-textured Rubicon soils, as the OM content of the mineral soil is very low, and increased OM decomposition could cause proportionally large losses. Since OM accounts for large percentages in mineral soil cation exchange capacity (CEC) (Brady and Weil 2008), this could also have severe negative implications for cation retention. Furthermore, loss of OM in the mineral soil could increase the infiltration rate of water (Brady and Weil 2008), which, along with the low inherent CEC of Rubicon soil (USDA NCSS 2011), could potentially lead to large leaching losses of cations. Beyond leaching losses, a reduction in mineral soil OM content could considerably increase the infiltration rate of water while decreasing the AWHC (Brady and Weil 2008). This could have serious negative implications for the future productivity of stands growing on these coarse-textured soils than nutrient removal as soil physical properties have been shown to play a larger role than nutrient availability in jack pine productivity (Pawluk and Arneman 1961).

Over time, atmospheric deposition and mineral weathering will help the soil recover from nutrient losses, but annual inputs are small, and it could take many years for a substantial amount of nutrients to be added. During the years 2000-2009, total deposition added an average of $13 \mathrm{~kg} / \mathrm{ha} /$ year available $\mathrm{N}, 0.2 \mathrm{~kg} / \mathrm{ha} /$ year Ca and $\mathrm{K}$, and $0.1 \mathrm{~kg} / \mathrm{ha} /$ year $\mathrm{Mg}$ in the Upper Peninsula of Michigan (NADP 2011). Using these estimates, deposition will add 845 $\mathrm{kg} / \mathrm{ha} \mathrm{N}, 13 \mathrm{~kg} / \mathrm{ha} \mathrm{Ca}, 13 \mathrm{~kg} / \mathrm{ha} \mathrm{K}$, and $6.5 \mathrm{~kg} / \mathrm{ha} \mathrm{Mg}$ during the first 65 years of growth. This will supply enough $\mathrm{N}$ to correct any $\mathrm{N}$ losses of available $\mathrm{N}$ following harvest, but the amount of cations added is far less than what will be needed by the regenerating stand.

Chemical weathering is the most important natural source of cations (Anderson 1988, Waring and Running 2007, Farve and Napper 2009), but it is unlikely that this will release enough cations for the next rotation. Johnson et al. (1968) estimated that $8.0 \mathrm{~kg} / \mathrm{ha} / \mathrm{year} \mathrm{Ca}$, $0.1 \mathrm{~kg} / \mathrm{ha} /$ year $\mathrm{K}$, and $1.8 \mathrm{~kg} / \mathrm{ha} /$ year $\mathrm{Mg}$ are released through weathering of a medium to coarse textured till soil in New Hampshire. Using these weathering rates, enough Ca and Mg would be released from minerals during the first 65 years of stand growth to replace cation losses following WTH. However, weathering rates are highly linked to the chemical and physical properties of the soil's parent material (Anderson 1988), and it is likely that weathering in Rubicon sand will be much lower. The quartz-dominated sand in these soils lacks rocks and minerals containing plant nutrients (Brady and Weil 2008), so the potential nutrient contribution by chemical weathering will likely be very small. High water infiltration rates in the Rubicon soil would also limit the amount of time during which chemical weathering can take place (Anderson 1988). 
Due to the possibility of large leaching losses, low soil nutrient reserves, and low cation input via deposition, all scenarios of WTH should be avoided on these and similar sites. With the exception of $\mathrm{Ca}$ in stand 3, $\mathrm{CH}$ will leave enough cations for the next rotation, but atmospheric deposition will not add enough cations to the surplus to support a subsequent stand. In the HNF, jack pine is typically left as retention at a density of approximately $2 \mathrm{~m}^{2} / \mathrm{ha}$ (Jean Perkins, personal communication). Increasing this density will help retain more nutrients, and could also help sustain the productivity of the soil resource. Hardwood species and red pine should also be left, as the presence of hardwoods in a conifer forest can increase the cycling of base cations (Prescott 2002). Furthermore, leaving live vegetation on-site may help to reduce the amount of nutrients lost through leaching, as the living trees will be able to take up newly available nutrients. While these nutrients will be sequestered in vegetative tissues, they will eventually be returned to the soil in litter rather than leached below the rooting zone. Retaining slash on-site could help regulate the soil temperature and reduce the possibility of increased OM decomposition (Hornbeck 1970, Kubin and Kemppainen 1991, Keenan and Kimmins 1993). The slash will also contain immobilized nutrients that will become available slowly during decomposition. This may help to reduce the amount of nutrients lost through leaching, but in order for $\mathrm{CH}$ to continue without creating productivity declines for future stands, hardwood species and red pine should be left behind. The amount of jack pine left as retention should also be increased, and rapid regeneration of jack pine, whether through planting or natural regeneration, should be encouraged in order to increase vegetative nutrient uptake.

\section{CONCLUSION}

The results of this study show the above- and below-ground biomass and nutrient pools in four jack pine stands in the Hiawatha National Forest. Each stand varied in age and species composition, but the amount of variation in biomass and nutrient content was relatively small. The results also indicate that $\mathrm{CH}$ will probably leave enough cations on-site for the next rotation, with the exception of $\mathrm{Ca}$ in stand 3 , but the cation surplus will be small and the addition of cations through atmospheric deposition will not add enough for the second rotation. WTH will likely result in Ca deficits in all stands, but this is more severe in stands 3 and 4 . WTH may also result in smaller deficits of $\mathrm{K}$ and $\mathrm{Mg}$. Where deficits do not occur, the surplus is so small that weathering and atmospheric deposition will not replenish the pool for the second rotation following WTH. Furthermore, the potential for increased decomposition and increased leaching loss may further increase nutrient loss. Due to these reasons, WTH should be avoided on these 
sites. Still, more work needs to be conducted in order to determine exactly how severe WTH could be to these sites. Tissue samples should be collected to obtain exact above-ground nutrient contents. Leaching losses following $\mathrm{CH}$ should be measured, and the soil should also be analyzed for available $\mathrm{N}$ and total mineral soil cations. These pieces of information would help strengthen the argument that WTH should be avoided on these sites in order to preserve the soil resource. 


\section{LITERATURE CITED}

Alban, D.H. 1988. Nutrient accumulation in planted red and jack pine. Res. Pap. NC-282. St. Paul, MN: U.S. Department of Agriculture, Forest Service, North Central Forest Experiment Station. 6p.

Alban, D.H., D.A. Perala, and B.E. Schlaegel. 1978. Biomass and nutrient distribution in aspen, pine, and spruce stands on the same soil type in Minnesota. Can. J. For. Res. 8: 290-299.

Anderson, D.W. 1988. The effect of parent material and soil development on nutrient cycling in temperate ecosystems. Biogeochemistry 5: 71-97.

Berg, B. and C. McClaugherty. 2003. Plant Litter: Decomposition, Humus Formation, Carbon Sequestration. Springer Verlag, Berlin. 286p.

Björheden, R. 2006. Drivers behind the development of forest energy in Sweden. Biomass and Bioenergy 30: 289-295.

Bot, A. and J. Benites. 2005. The importance of soil organic matter: Keys to drought resistant soil and sustained food and production. Rome: Food and Agriculture Organization of the United Nations. 95p.

Brady, N.C. and R.R. Weil. 2008. The Nature and Properties of Soils. 14th ed. Pearson Education, Inc., Upper Saddle River, NJ. 975p.

Broadfoot, W.M. and H.D. Burke. 1958. Soil-moisture constants and their variation. U.S. Department of Agriculture, Forest Service, Southern Forest Experiment Station. Occasional Paper 166. 27p.

Burger, T.L. and J. Kotar. 2003. A guide to forest communities and habitat types of Michigan. Department of Forest Ecology and Management. Madison, WI. 361p.

Crow, T.R., G.D. Mroz, and M.R. Gale. 1991. Regrowth and nutrient accumulations following whole-tree harvesting of a maple-oak forest. Can. J. For. Res. 21: 1305-1315.

Egnell, G. and B. Leijon. 1999. Survival and growth of planted seedlings of Pinus sylvestris and Picea abies after different levels of biomass removal in clear-felling. Scand. J. For. Res. 14(3): 303-311.

Egnell, G. and E. Valinger. 2003. Survival, growth, and growth allocation of planted Scots pine trees after different levels of biomass removal in clear-felling. For. Ecol. Mgmt. 177: 6574.

Farve R. and C. Napper. 2009. Biomass fuels \& whole-tree harvesting impacts on soil productivity-Review of literature. U.S. Department of Agriculture, Forest Service. National Technology and Development Program. 2000_Inventory \& Monitoring 0920 1803-SDTDC. 60p.

Foster N.W. and I.K. Morrison. 1976. Distribution and cycling of nutrients in a natural Pinus banksiana ecosystem. Ecology 57: 110-120. 
Green, D.C. and D.F. Grigal. 1980. Nutrient accumulations in jack pine stands on deep and shallow soils over bedrock. For. Sci. 26: 325-333.

Grigal, D.F. 2000. Effects of extensive forest management on soil productivity. For. Ecol. Mgmt. 138: 167-185.

Hakkila, P. 2006. Factors driving the development of forest energy in Finland. Biomass and Bioenergy 30: 281-288.

Helmisaari, H.S., K.H. Hanssen, S. Jacobson, M. Kukkola, J. Luiro, A. Saarsalmi, P. Tamminen, B. Tveite. 2011. Logging residue removal after thinning in Nordic boreal forests: Longterm impact on tree growth. For. Ecol. Mgmt. doi: 10.1016/j.foreco.2011.02.015

Hendrickson, O.Q., L. Chatarpaul, and D. Burgess. 1989. Nutrient cycling following whole-tree and conventional harvest in northern mixed forest. Can. J. For. Res. 19: 725-735.

Herrick, S.K., J.A. Kovach, E.A. Padley, C.R. Wagner. 2008. Wisconsin's forestland woody biomass harvesting guidelines: Rationale for the guidelines. DRAFT (Draft not for distribution). Wisconsin Department of Natural Resources, Division of Forestry. Madison, WI. June 12, 2008.

Hornbeck, J.W. 1970. The radiant energy budget of clearcut and forested sites in West Virginia. For. Sci. 16: 139-145.

Jacobson, S., M. Kukkola, E. Mälkönen, B. Tveite, G. Möller. 1996. Growth response of coniferous stands to whole-tree harvesting in early thinning. Scand. J. For. Res. 11: 5059.

Jacobson, S.; Kukkola, M.; Malkonen, E.; Tveite, B. 2000. Impact of whole-tree harvesting and compensatory fertilization on growth of coniferous thinning stands. Forest Ecol. Mgmt. 129: $41-51$.

Jerome, Dwight S. 2006. Landforms of the Upper Peninsula, Michigan. USDA Natural Resource Conservation Service. Draft. 56p.

Johnson, N.M., G.E. Likens, F.H. Bormann, and R.S. Pierce. 1968. Rate of chemical weathering of silicate minerals in New Hampshire. Geochim. Cosmochim. Acta 32: 531545.

Jurgensen, M.F., et al. 1997. "Impacts of Timber Harvesting on Soil Organic Matter, Nitrogen, Productivity, and Health of Inland Northwest Forests." For. Sci. 43: 234-251.

Keach, K. Personal communication. Timber Resource Specialist, Hiawatha National Forest. March 11, 2011.

Keenan, R.J. and J.P. Kimmins. 1993. The ecological effects of clear-cutting. Environ. Rev. 1: 121-144.

Knoepp, J.D. and W.T. Swank. 1997. Forest management effects on soil surface soil carbon and nitrogen. Soil Sci. Soc. Am. J. 61: 928-935. 
Kubin, E. and L. Kemppainen. 1991. Effect of clearcutting of boreal spruce on air and soil temperature conditions. Tiivistelmä: Avohakkuun vaikutus kuusimetsän lämpöoloihin. Acta Forestalia Fennica 225. 42p.

MacLean, D.A. and R.W. Wein. 1976. Biomass of jack pine and mixed hardwood stands in northeastern New Brunswick. Can. J. For. Res. 6: 441-447.

Mann, L.K., et al. 1988. Effects of whole-tree and stem-only clearcutting on postharvest hydrologic losses, nutrient capital, and regrowth. For. Sci. 34: 412-428.

Marks, P.L. 1974. The role of pin cherry (Prunus pensylvanica L.) in the maintenance of stability in northern hardwood ecosystems. Ecol. Monogr. 44: 73-88.

Michigan Department of Natural Resources. 2010. Michigan Woody Biomass Harvesting Guidance. Michigan Department of Natural Resources Forest Management Division, Lansing, MI.

Minnesota Forest Resources Council. 2005. Sustaining Minnesota Forest Resources: Voluntary Site-Level Forest Management Guidelines for Landowners, Loggers and Resource Managers. Minnesota Forest Resources Council, St.Paul, MN.

Mohney, P. Personal communication. Forester, Michigan Department of Natural Resources, Grayling Management Unit. March 8, 2011.

Morrison, I.K. 1973. Distribution of elements in aerial components of several natural jack pine stands in northern Ontario. Can. J. For. Res. 3: 170-179.

National Atmospheric Deposition Program. 2011. Annual Data for MI48: Sceney National Wildlife Refuge Headquaters. Available online at:

http://nadp.sws.uiuc.edu/nadpdata/annualReq.asp?site=MI48; Last accessed March 28, 2011.

Nave, L.E., E.D. Vance, C.W. Swanston, and P.S. Curtis. 2010. Harvest impacts on soil carbon storage in temperate forests. For. Ecol. Mgmt. 259: 857-866.

Olsson, B.A., H. Staaf, H. Lundkvist, J. Bengtsson, and K. Rosén. 1996. Carbon and nitrogen in coniferous forest soils after clear-felling and harvests of different intensity. For. Ecol. Mgmt. 82: 19-32.

Page-Dumroese, D.S, M. Jurgensen, T. Terry. 2010. Maintaining soil productivity during forest for biomass-to-energy thinning in harvests in the Western United States. West. J. Appl. For. 25: 5-11.

Pawluk, S. and H.F. Arneman. 1961. Some forest soil characteristics and their relationship to jack pine growth. For. Sci. 7: 160-173.

Perala, D.A. and D. H. Alban 1993. Allometric Biomass Estimators for Aspen-Dominated Ecosystems in the Upper Great Lakes. USDA Forest Service. North Central Forest Experiment Station, St. Paul, MN. NC-314. 38p. 
Perala, D.A. and D.H. Alban. 1982. Biomass, nutrient distribution and litterfall in Populus, Pinus, and Picea on two different soils in Minnesota. Plant and Soil 64: 177-192.

Perkins, J. Personal Communication. Forest Silviculturist, Hiawatha National Forest. February 28, 2011.

Powers, R.F., et al. 2004. The North American long-term soil productivity experiment: Coastto-coast findings from the first decade. U.S. Department of Agriculture, Forest Service Proceedings RMRS-P-34. 16p.

Powers, R.F., et al. 1990. Sustaining site productivity in North American forests: Problems and prospects. In: Sustained productivity of forest soils: 7th North American Forest Soils Conference. University of British Columbia, Vancouver, B.C. p 49-79.

Prescott, C.E. 2002. The influence of the forest canopy on nutrient cycling. Tree Physiol. 22: 1193-1200.

Rothstein, D.E. and S.E. Spaulding. 2010. Replacement of wildfire by whole-tree harvesting in jack pine forests: Effects on soil fertility and tree nutrition. Forest Ecol. Mgmt. 260: 1164-1174.

Rudolph, T.D. 1985. Jack pine: An American Wood. U.S. Department of Agriculture, Forest Service, North Central Forest Experiment Station. FS-252. 7p.

Rutkowski, D. R., and R. Stottlemyer. 1993. Composition, Biomass and Nutrient Distribution in Mature Nothern Hardwood and Boreal Forest Stands, Michigan. American Midland Naturalist 130: 13-30.

Saarsalmi, A., P. Tamminen, M. Kukkola, and R. Hautajärvi. 2010. Whole-tree harvesting at clear-felling: Impact on soil chemistry, needle nutrient concentrations and growth of Scots pine. Scand. J. For. Res. 25: 148-156.

Stone, D.M., J.A. Gates, and J.D. Elioff. 1998. Are we maintaining aspen productivity on sand soils? In Conference Proceedings from Improving Forest Productivity for Timber: A key to Sustainability. Dec. 1, 2, 3, 1998. Duluth, Minnesota.

Swift, M.J, O.W. Heal, and J.M. Anderson. 1979. Decomposition in Terrestrial Ecosystems. Studies in Ecology, Vol. 5. University of California Press, Berkeley, CA. 372p.

Thiffault, E., D. Paré, N. Bélanger, A. Munson, and F. Marquis. 2006. Harvesting intensity at clear-felling in the boreal forest: Impact on soil and foliar nutrient status. Soil Sci. Soc. Am. J. 70: 691-701.

USDA Forest Service. 2006. Hiawatha National Forest 2006 Forest Plan. 169p.

USDA Forest Service. 2007. Hiawatha National Forest, Ecological Classification System, FIELD GUIDE version 8.5. Last edited by J. Gries May 7, 2007. 86p.

USDA National Cooperative Soil Survey. 2011. National Cooperative Soil Characterization Database. Available online at http://ssldata.nrcs.usda.gov. Monday, February 21, 2011. 
USDA National Resource Conservation Service. 2010. Grafton Series. Available online at https://soilseries.sc.egov.usda.gov/osdname_look.aspx; last accessed March 20, 2011.

USDA Natural Resource Conservation Service. 2006a. Official Series Description, Redby Series. Available online at https://soilseries.sc.egov.usda.gov/OSD_Docs/R/REDBY.html; last accessed Dec. 9, 2010.

USDA Natural Resource Conservation Service. 2006b. Official Series Description, Kalkaska Series. Available online at http://www2.ftw.nrcs.usda.gov/osd/dat/K/KALKASKA.html; last accessed Dec. 9, 2010.

USDA Natural Resource Conservation Service. 2009a. Official Series Description, Rubicon Series. Available online at http://www2.ftw.nrcs.usda.gov/osd/dat/R/RUBICON.html; last accessed Sept. 29, 2010.

USDA Natural Resource Conservation Service. 2009b. Web Soil Survey. Available online at http://websoilsurvey.nrcs.usda.gov/app/HomePage.htm; last accessed April 18, 2011.

Walmsley, J.D., D.L. Jones, B. Reynolds, M.H. Price, and J.R. Healy. 2009. Whole tree harvesting can reduce second rotation forest productivity. For. Ecol. Mgmt. 257: 11041111.

Waring, R.H. and S.W. Running. 2007. Forest Ecosystems: Analysis at multiple scales. 3rd edition. Elsevier Academic Press, San Diego, CA. 420p.

Weber, M.G., I.R. Methven, and C.E. Wagner. 1985. The effect of forest floor manipulation on nitrogen status and tree growth in an eastern Ontario jack pine ecosystem. Can. J. For. Res. 15: 313-318.

Weetman G.F. and D. Algar. 1983. Low-site class black spruce and jack pine nutrient removals after full-tree and tree-length logging. Can. J. For. Res. 13: 1030-1036.

Woodall, C. and M. S. Williams. 2005. Sampling Protocol, Estimation, and Analysis Procedures for the Down Woody Materials Indicator of the FIA Program. USDA Forest Service. North Central Research Station, St. Paul, MN. NC-256. 56p. 


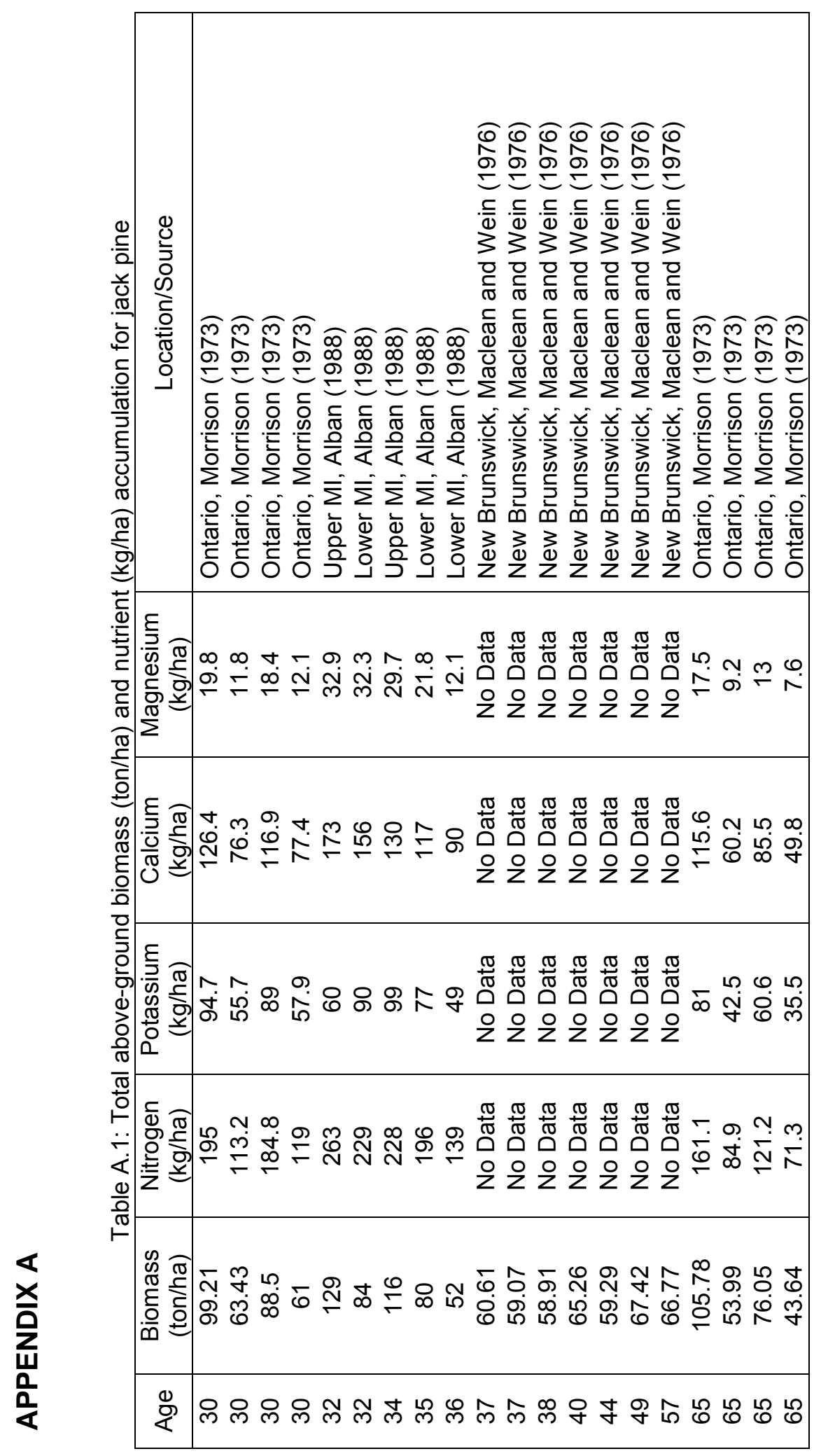




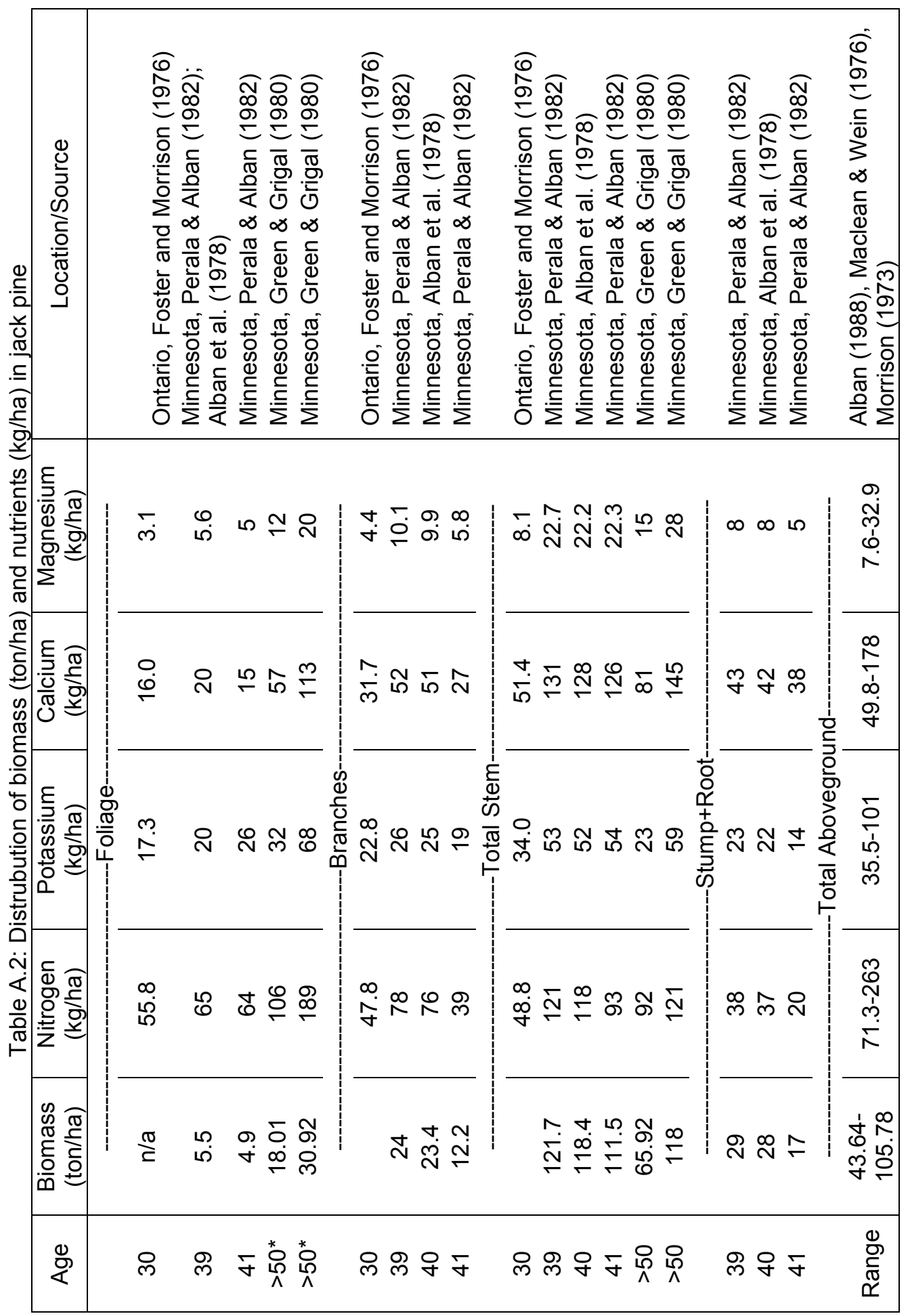


Table A.3: Soil nutrient content under jack pine (Perala and Alban 1982)

\begin{tabular}{|c|c|c|c|c|c|}
\hline Depth & $\begin{array}{l}\text { Organic } \\
\text { Matter } \\
\text { ton/ha }\end{array}$ & Total N & $\begin{array}{l}\text { Available K } \\
\end{array}$ & $\begin{array}{l}\text { Available } \\
\text { Ca }\end{array}$ & $\begin{array}{c}\text { Available } \\
\text { Mg }\end{array}$ \\
\hline Loam: & & & & & \\
\hline Forest Floor & 33 & 700 & 68 & 770 & 81 \\
\hline $0-10 \mathrm{~cm}$ & 48 & 1731 & 94 & 2080 & 134 \\
\hline $10-25 \mathrm{~cm}$ & 14 & 640 & 98 & 1029 & 83 \\
\hline $25-30 \mathrm{~cm}^{\mathrm{a}}$ & 2 & 116 & 40 & 315 & 48 \\
\hline Total & 97 & 3187 & 300 & 4194 & 346 \\
\hline Sand: & & & & & \\
\hline Forest Floor & 25 & 468 & 37 & 375 & 50 \\
\hline $0-10 \mathrm{~cm}$ & 44 & 1382 & 99 & 1496 & 138 \\
\hline $10-25 \mathrm{~cm}$ & 24 & 666 & 107 & 977 & 131 \\
\hline $25-30 \mathrm{~cm}^{\mathrm{a}}$ & 3 & 123 & 32 & 209 & 31 \\
\hline Total & 96 & 2639 & 275 & 3030 & 350 \\
\hline
\end{tabular}

${ }^{\mathrm{a}}$ Extrapolated from $25-36 \mathrm{~cm}$ 


\section{APPENDIX B}

Table B.1: Equations used to estimate biomass (From Perala and Alban 1993)

\begin{tabular}{|c|c|c|c|c|c|c|}
\hline Species & Jack pine & Red pine & Red maple & $\begin{array}{c}\text { Quaking } \\
\text { aspen }\end{array}$ & Red Oak & Pin Cherry \\
\hline Height & & 0.5213 & & $\begin{array}{c}2.391^{*} \mathrm{DBH}^{\wedge} \\
0.5296\end{array}$ & $\begin{array}{c}3.707^{*} \mathrm{DBH}^{\wedge} \\
0.4932\end{array}$ & $\begin{array}{c}2.313^{*} \mathrm{DBH}^{\wedge} \\
0.562\end{array}$ \\
\hline Foliage & $\begin{array}{l}0.0008988^{*} \\
\mathrm{DBH}^{\wedge} 2.903\end{array}$ & & $\begin{array}{c}0.01913^{*} \mathrm{DB} \\
\mathrm{H}^{\wedge} 1.867\end{array}$ & $\begin{array}{c}0.00274^{\star} \mathrm{DB} \\
\mathrm{H}^{\wedge} 2.275\end{array}$ & $\begin{array}{c}0.04801^{*} \mathrm{DB} \\
\mathrm{H}^{\wedge} 1.455\end{array}$ & $\begin{array}{c}0.02979^{\star} \mathrm{DB} \\
\mathrm{H}^{\wedge} 2.582^{*} \mathrm{H}^{\wedge}- \\
0.913\end{array}$ \\
\hline $\begin{array}{l}\text { Live } \\
\text { Limb }\end{array}$ & $\begin{array}{c}0.002956 * \mathrm{D} \\
\mathrm{BH}^{\wedge} 2.830\end{array}$ & $\begin{array}{c}0.031 \\
\mathrm{H}^{\wedge} 4.0 \\
2 .\end{array}$ & $\begin{array}{r}\wedge 2.84 \\
.\end{array}$ & $\begin{array}{c}0.06059^{*} \mathrm{DB} \\
\mathrm{H}^{\wedge} 3.806^{*} \mathrm{H}^{\wedge}- \\
2.033\end{array}$ & $\begin{array}{c}0.01684^{*} \mathrm{DB} \\
\mathrm{H}^{\wedge} 2.514\end{array}$ & $\begin{array}{c}0.04189^{*} \mathrm{DB} \\
\mathrm{H}^{\wedge} 3.54^{*} \mathrm{H}^{\wedge}- \\
1.58\end{array}$ \\
\hline $\begin{array}{l}\text { Dead } \\
\text { Limb }\end{array}$ & $\begin{array}{r}0.239 \\
\wedge 2.94 \\
1 .\end{array}$ & $\begin{array}{l}0.0005819^{*} \\
\mathrm{DBH}^{\wedge} 2.714\end{array}$ & $\begin{array}{c}0.00338^{*} \mathrm{DB} \\
\mathrm{H}^{\wedge} 2.337\end{array}$ & $\begin{array}{c}0.001631^{*} \mathrm{D} \\
\mathrm{BH}^{\wedge} 3.33^{*} \mathrm{H}^{\wedge}- \\
1.552\end{array}$ & $\begin{array}{c}0.000478^{*} \mathrm{D} \\
\mathrm{BH}^{\wedge} 3.125\end{array}$ & $\begin{array}{c}0.009592^{\star} \mathrm{D} \\
\mathrm{BH}^{\wedge} 2.224\end{array}$ \\
\hline $\begin{array}{l}\text { Bole } \\
\text { Bark }\end{array}$ & $\begin{array}{r}0.015 \\
\wedge 1.77 \\
39\end{array}$ & $\begin{array}{c}0.01408^{*} 2.0 \\
9\end{array}$ & $\begin{array}{c}0.02102^{*} \mathrm{DB} \\
\mathrm{H}^{\wedge} 2.191\end{array}$ & $\begin{array}{c}0.005244^{*} \mathrm{D} \\
\mathrm{BH}^{\wedge} 1.855^{\star} \mathrm{H} \\
\wedge 0.8777\end{array}$ & $\begin{array}{r}0.004 \\
\mathrm{BH}^{\wedge} 2 \\
\wedge 0.8\end{array}$ & $\begin{array}{c}0.03156^{*} \mathrm{DB} \\
\mathrm{H}^{\wedge} 1.846^{\star} \mathrm{H}^{\wedge} \\
0.666\end{array}$ \\
\hline $\begin{array}{l}\text { Bole } \\
\text { Wood }\end{array}$ & $\begin{array}{c}0.01395^{\star} \mathrm{DB} \\
\mathrm{H}^{\wedge} 1.709^{\star} \mathrm{H}^{\wedge} \\
1.327\end{array}$ & $\begin{array}{c}0.02137^{*} \mathrm{DB} \\
\mathrm{H}^{\wedge} 1.809^{\star} \mathrm{H}^{\wedge} \\
1.037\end{array}$ & $\begin{array}{c}0.02347^{*} \mathrm{DB} \\
\mathrm{H}^{\wedge} 1.888^{\star} \mathrm{H}^{\wedge} \\
0.9912\end{array}$ & $\begin{array}{c}0.01516^{\star} \mathrm{DB} \\
\mathrm{H}^{\wedge} 2.053^{\star} \mathrm{H}^{\wedge} \\
0.8777\end{array}$ & $\begin{array}{c}0.02635^{\star} \mathrm{DB} \\
\mathrm{H}^{\wedge} 1.88^{\star} \mathrm{H}^{\wedge} 0 . \\
979\end{array}$ & $\begin{array}{c}0.02869^{\star} \mathrm{DB} \\
\mathrm{H}^{\wedge} 1.886^{*} \mathrm{H}^{\wedge} \\
0.9768\end{array}$ \\
\hline $\begin{array}{c}\text { Stump+ } \\
\text { Root }\end{array}$ & $\begin{array}{c}0.09178^{*} \mathrm{DB} \\
\mathrm{H}^{\wedge} 2.498^{*} \mathrm{H}^{\wedge}- \\
0.6471\end{array}$ & $\begin{array}{c}0.09178^{*} \mathrm{DB} \\
\mathrm{H}^{\wedge} 2.498^{*} \mathrm{H}^{\wedge}- \\
0.6471\end{array}$ & $\begin{array}{c}0.09178^{*} \mathrm{DB} \\
\mathrm{H}^{\wedge} 2.498^{*} \mathrm{H}^{\wedge}- \\
0.6471\end{array}$ & $\begin{array}{c}0.09178^{*} \mathrm{DB} \\
\mathrm{H}^{\wedge} 2.498^{*} \mathrm{H}^{\wedge}- \\
0.6471\end{array}$ & $\begin{array}{c}0.09178 * \mathrm{DB} \\
\mathrm{H}^{\wedge} 2.498^{*} \mathrm{H}^{\wedge}- \\
0.6471\end{array}$ & $\begin{array}{c}0.09178^{*} \mathrm{DB} \\
\mathrm{H}^{\wedge} 2.498^{*} \mathrm{H}^{\wedge}- \\
0.6471\end{array}$ \\
\hline
\end{tabular}

$\mathrm{DBH}$ : Diameter at breast height $(\mathrm{cm})$

$\mathrm{H}$ : Height (m)

Table B.2: Equations used to estimate CWD weight and C (Woodall and Williams 2005)

\begin{tabular}{l|c|}
\hline Weight $(\mathrm{kg} / \mathrm{ha})$ & $\left.\left[(\pi / 2 \mathrm{~L})^{\star}\left(\mathrm{V} / \mathrm{i}_{\mathrm{i}}\right)^{\star} \mathrm{f}\right)\right]^{*}\left(1000^{\star} \mathrm{G}\right)$ \\
\hline $\mathrm{Mg} \mathrm{C}$ & $\left.\left[(\pi / 2 \mathrm{~L})^{*}\left(\mathrm{~V} / \mathrm{i}_{\mathrm{i}}\right)^{\star} \mathrm{f}\right)\right]^{*}\left(0.521^{*} \mathrm{G}\right)$ \\
\hline $\mathrm{L}=$ Total length of the transect \\
$\mathrm{I}_{\mathrm{i}}=$ Length of individual CWD piece $(\mathrm{m})$ \\
$\mathrm{V}=$ Volume of individual piece $\left(\mathrm{m}^{3}\right)$ \\
$\mathrm{f}=$ Conversion factor $\left(10,000 \mathrm{~m}^{2} / \mathrm{ha}\right)$ \\
$\mathrm{G}=$ Specific gravity (Decay class 1 \& $2: 0.40,3$ \& $4: 0.30$ )
\end{tabular}


Table B.3: Nutrient concentrations used to estimated stand nutrient content

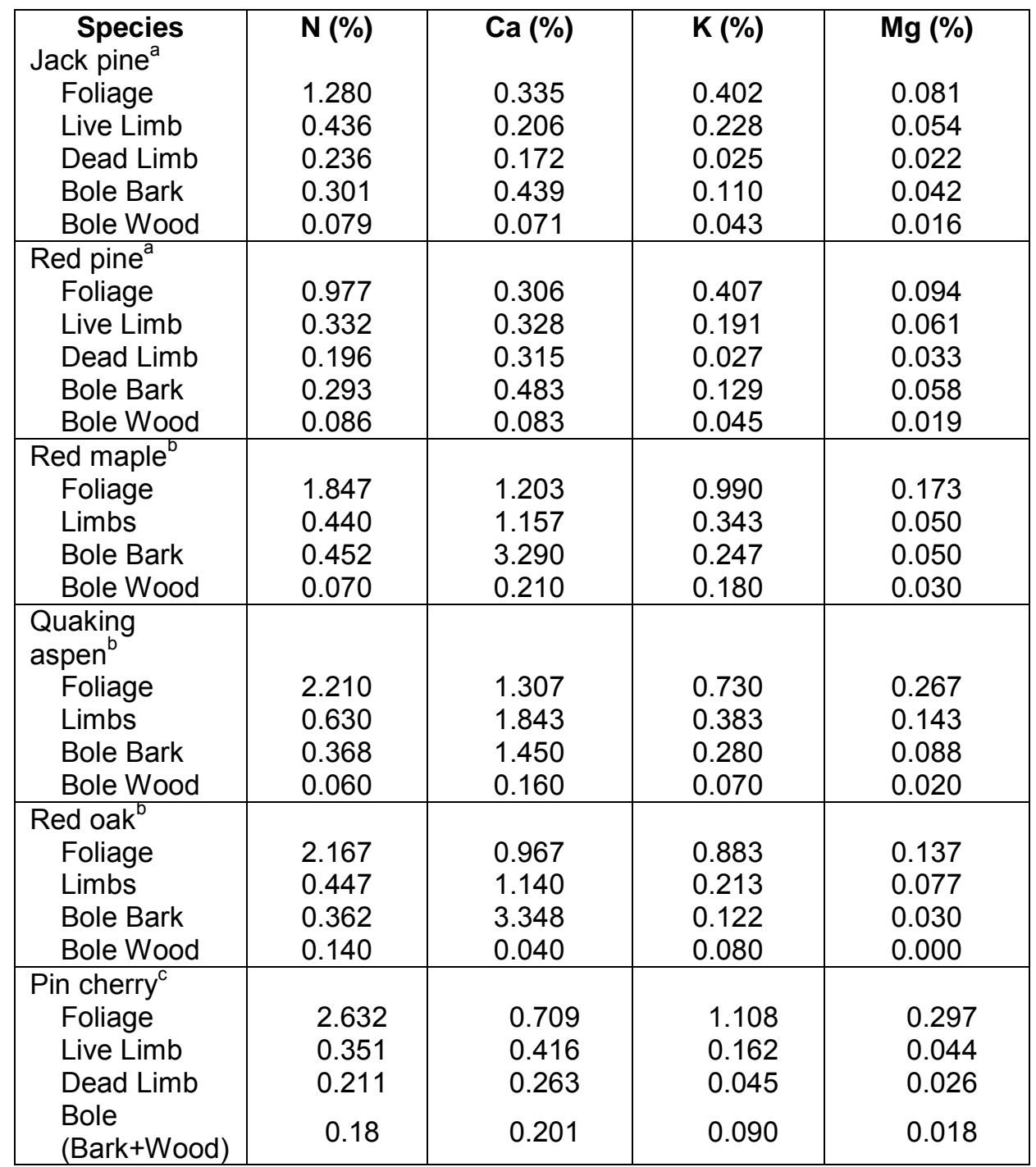

aAlban (1988)

bRutkowski and Stottlemyer (1993)

cMarks (1974) 